\title{
Phytoplankton diversity during the spring bloom in the northwestern Mediterranean Sea
}

\author{
Isabella Percopo',*, Raffaele Siano, ${ }^{1,2, a}$, Federica \\ Cerino $^{1, b}$, Diana Sarno ${ }^{2}$ and Adriana Zingone ${ }^{1}$ \\ ${ }^{1}$ Ecology and Evolution of Plankton, Stazione Zoologica \\ Anton Dohrn, Villa Comunale 80121 Naples, Italy, \\ e-mail: percopo@szn.it \\ 2 Taxonomy and Identification of Marine Phytoplankton, \\ Stazione Zoologica Anton Dohrn, Villa Comunale 80121 \\ Naples, Italy \\ * Corresponding author
}

\begin{abstract}
The section of the Liguro-Provençal basin north of the Balearic Islands is one of the most productive sites in the whole Mediterranean Sea, with intense phytoplankton bloom lasting about 2 months in late winter-early spring. The phytoplankton species composition of the area was investigated using light and electron microscopy to analyze bottle and net samples collected at several stations in spring 2000 and 2003. Serial dilution cultures established from bottle samples were also examined. A total of 168 phytoplankton taxa was identified, consisting of 73 Coscinodiscophyceae, 47 Dinophyceae, 25 Coccolithophyceae and 4 Prymnesiophyceae, 5 Prasinophyceae, 3 Chrysophyceae, 2 Cryptophyceae, 2 Dictyochophyceae, 1 Euglenophyceae, 1 Pelagophyceae, 1 Choanoflagellidea, 1 Filosea and 3 incertae sedis. We also provided a brief taxonomic description and original micrographs for 25 of the smallest and/or less known species identified in the study area, which may go undetected during routine microscopical analysis of fixed samples. Among these, 10 species were recorded for the first time in the Mediterranean Sea, confirming the need of detailed studies to reveal the biodiversity and biogeography of Mediterranean phytoplankton.
\end{abstract}

Keywords: check-list; diversity; NW Mediterranean Sea; phytoplankton; serial dilution cultures.

\section{Introduction}

The Mediterranean Sea is considered as a miniature ocean (Lacombe et al. 1981, Robinson and Golnaraghi 1995) characterized by a prevalently oligotrophic condition (Azov

\footnotetext{
a Present address: IFREMER, Centre de Brest, DYNECO/Pelagos, BP 70, 29280 Plouzané, France.

${ }^{\mathrm{b}}$ Present address: Department of Biological Oceanography, Istituto Nazionale di Oceanografia e Geofisica Sperimentale (OGS), via Picard 54, 34151 S. Croce (TS), Italy.
}

1991, Sur et al. 1993, Antoine and Morel 1995, Williams 1998, Duarte et al. 1999). In contrast to other oceans, the Mediterranean Sea has no intense upwelling zones and its deep waters are characterized by very low nutrient concentrations. The extreme oligotrophy of most Mediterranean areas is offset by the presence of a complex hydrography, with deep convection areas, fronts, and gyres where primary production and biomass values are relatively high (Siokou-Frangou et al. 2010). One of these areas is the Liguro-Provençal basin, which is located in the northwestern sector of the Mediterranean basin, south of the French coast and north of the North Balearic front, between the Balearic Islands and Sardinia. In that zone, intense northwesterly winds induce strong vertical movements that promote phytoplankton blooms lasting over 60 days, generally in February and March. These blooms are clearly detected by satellite imagery (D'Ortenzio and Ribera d'Alcalà 2009) and are responsible for approximately $15 \%$ of Mediterranean primary production (Marshall and Schott 1979).

In the Liguro-Provençal basin, physical and biogeochemical aspects of offshore waters have been intensively investigated (MEDOC 1970, Gascard 1978, Millot 1987, 1999, Levy et al. 1999, Anderson and Prieur 2000). Information on phytoplankton taxonomic composition is available for nearby coastal areas of the Gulf of Marseille (Gourret 1883, Travers 1971, 1975), Gulf of Lyon (Peragallo and Peragallo 1897-1908, Pavillard 1905, 1916a,b) and the Catalan Sea (Margalef 1969, 1974, Delgado 1990, Descy and Willems 1991), as well as for open waters of the Gulf of Lyon (Velasquez and Cruzado 1995) and the North Balearic front (Estrada 1982, 1991, Delgado et al. 1992, Margalef 1995, Estrada et al. 1999). More extensive phytoplankton assessments of these areas focusing mainly on diatoms and dinoflagellates were published by Velasquez and Cruzado (1995) and Gómez (2003), respectively. Some information on nanoflagellates of the northwestern Mediterranean Sea was reported by Delgado and Fortuño (1991), including scanning electron micrographs of many dinoflagellates, diatoms, and coccolithophores. The latter group was investigated in depth by Cros and Fortuño (2002), who provided a comprehensive iconography of numerous species based on scanning electron microscopy, highlighting the high diversity of this group in the Mediterranean Sea. However, the areas so far investigated only marginally overlap with the Liguro-Provençal basin, where phytoplankton species composition is still poorly known.

In this paper, we present an overview of the phytoplankton species composition in the offshore area of the Liguro-Provençal basin during the late winter-early spring of two different years. Our specific aims were to characterize the diversity of the phytoplankton in this area during the bloom 
period and to contribute to the knowledge of the biogeography of the recorded species. In addition, we provide some morphological information on several small and/or poorly known species, which may go undetected because they have a small size, are difficult to identify with traditional methods, and have limited available iconography. The present study was motivated by the need for a better characterization of the marine phytoplankton species composition in one of the most productive areas of the Mediterranean Sea.

\section{Materials and methods}

\section{Study area and sampling}

The study area $\left(4^{\circ} 29.98-6^{\circ} 15.02 \mathrm{E}\right.$ and $40^{\circ} 44.98-$ $42^{\circ} 30.00 \mathrm{~N}$ ) is located in the central part of the Ligurian Sea, and is delimited by the Sardinian coast and Balearic Islands. It is a highly dynamic area, where complex physical forcing brings nutrients from deep water into the euphotic zone, thus contributing to enhanced phytoplankton new production. During winter, a deep-mixed layer of dense water is formed; it is rich in nutrients (Coste et al. 1972). The breakup of this patch during mixing events, followed by a rapid restratification of the surface waters causes the onset of the bloom (Jacques et al. 1973). These mixing and stratification phases cause this bloom to last about 2 months.

Samples were collected within the project NORBAL (NORth BALearic) during three oceanographic cruises in April-May 2000 (NORBAL 1), March 2003 (NORBAL 4), and April 2003 (NORBAL 5), with 29 stations visited (Figure 1 and Table 1). At each station, temperature and salinity were sampled using a SBE 911 plus CTD probe (Seabird, Bellevue, WA, USA). A total of 69 water samples $(250 \mathrm{ml})$ were collected with 201 Niskin bottles at surface $(0-5 \mathrm{~m})$ and at different depths (Table 1). Samples were fixed with formaldehyde $(0.8 \%$ final concentration) neutralized with $\mathrm{CaCO}_{3}$. Some additional net samples were collected by horizontal tows with a $20-\mu \mathrm{m}$ mesh-size plankton net during NORBAL 1 and 4.

\section{Serial dilution cultures}

Twenty samples collected during NORBAL 4 and 5 were used to establish serial dilution cultures (SDCs). Following the method of Andersen and Throndsen (2003), five replicates of five 1:10 dilution steps (from $1 \mathrm{ml}$ to $0.1 \mu \mathrm{l}$ ) per sample were incubated in K-medium (Keller et al. 1987) without addition of silicate and kept at $21^{\circ} \mathrm{C}$ at an irradiance of 70-80 $\mu \mathrm{mol}$ photon $\mathrm{m}^{-2} \mathrm{~s}^{-1}$ and a 12:12 light:dark regime. Culture tubes containing growing algae were examined in light microscopy after 3-6 weeks incubation.

\section{Microscopical examination}

All samples were examined in light microscopy (LM) using bright field (BF), phase contrast (PC) and differential interference contrast (DIC) optics with Zeiss Axiophot and Axiovert 200 light microscopes (Carl Zeiss, Oberkochen, Germany) equipped with a Zeiss Axiocam digital camera.

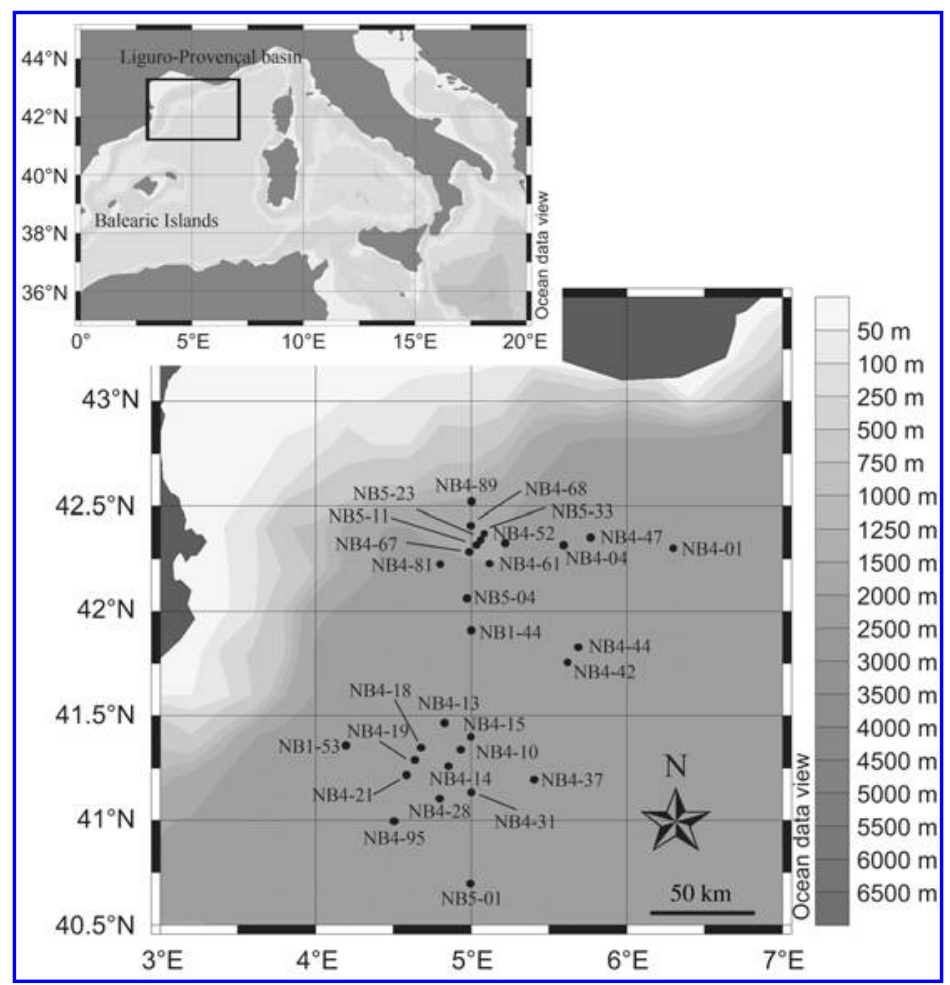

Figure 1 Location of the sampling stations in the Liguro-Provençal basin in the northwestern Mediterranean Sea visited during spring 2000 and 2003. 
Table 1 Sampling locations from the Liguro-Provençal basin in the northwestern Mediterranean Sea during three NORBAL (NB) cruises in 2000 and 2003.

\begin{tabular}{|c|c|c|c|c|c|c|c|}
\hline Cruise & Station & $\begin{array}{l}\text { Depth } \\
\text { (m) }\end{array}$ & $\begin{array}{l}\text { Latitude } \\
\text { North }\end{array}$ & $\begin{array}{l}\text { Longitude } \\
\text { East }\end{array}$ & Date & $\begin{array}{l}\text { Temperature } \\
\left({ }^{\circ} \mathrm{C}\right)\end{array}$ & Salinity \\
\hline \multirow[t]{4}{*}{ NB1 } & 44 & 0 & $41^{\circ} 50.06$ & $05^{\circ} 00.09$ & 8 April 2000 & 13.1 & 38.4 \\
\hline & & 30 & & & & 13.1 & 38.4 \\
\hline & 53 & 5 & $41^{\circ} 19.98$ & $04^{\circ} 29.98$ & 13 April 2000 & 13.5 & 38.3 \\
\hline & & 15 & & & & 13.5 & 38.3 \\
\hline \multirow[t]{50}{*}{ NB4 } & 01 & 0 & $42^{\circ} 14.98$ & $06^{\circ} 15.02$ & 6 March 2003 & 12.8 & 38.2 \\
\hline & 04 & 0 & $42^{\circ} 15.00$ & $05^{\circ} 30.00$ & 7 March 2003 & 13.0 & 38.5 \\
\hline & 10 & 5 & $41^{\circ} 22.48$ & $04^{\circ} 59.99$ & 8 March 2003 & 13.0 & 38.3 \\
\hline & & 50 & & & & 13.0 & 38.4 \\
\hline & & 70 & & & & 13.0 & 38.4 \\
\hline & 13 & 5 & $41^{\circ} 24.48$ & $04^{\circ} 51.97$ & 9 March 2003 & 12.8 & 38.2 \\
\hline & & 20 & & & & 13.0 & 38.3 \\
\hline & & 50 & & & & 13.0 & 38.3 \\
\hline & 14 & 0 & $41^{\circ} 14.46$ & $04^{\circ} 57.39$ & 9 March 2003 & nd & nd \\
\hline & 15 & 5 & $41^{\circ} 21.24$ & $04^{\circ} 57.18$ & 10 March 2003 & 13.0 & 38.2 \\
\hline & & 20 & & & & 12.9 & 38.3 \\
\hline & & 100 & & & & 12.8 & 38.3 \\
\hline & 18 & 0 & $41^{\circ} 17.99$ & $04^{\circ} 51.02$ & 10 March 2003 & 13.0 & 38.2 \\
\hline & & 20 & & & & 12.8 & 38.2 \\
\hline & & 70 & & & & 12.9 & 38.3 \\
\hline & 19 & 5 & $41^{\circ} 15.04$ & $04^{\circ} 46.99$ & 11 March 2003 & 13.0 & 38.3 \\
\hline & & 20 & & & & 12.8 & 38.2 \\
\hline & & 70 & & & & 12.8 & 38.3 \\
\hline & 21 & 5 & $41^{\circ} 11.70$ & $04^{\circ} 43.63$ & 11 March 2003 & 13.2 & 38.2 \\
\hline & & 20 & & & & 12.8 & 38.2 \\
\hline & & 50 & & & & 12.8 & 38.2 \\
\hline & & 100 & & & & 12.9 & 38.3 \\
\hline & 28 & 5 & $41^{\circ} 04.32$ & $04^{\circ} 51.70$ & 12 March 2003 & 13.2 & 38.2 \\
\hline & & 20 & & & & 13.0 & 38.2 \\
\hline & & 50 & & & & 12.9 & 38.3 \\
\hline & 31 & 0 & $41^{\circ} 07.43$ & $05^{\circ} 00.85$ & 12 March 2003 & 13.4 & 38.2 \\
\hline & & 10 & & & & 13.4 & 38.2 \\
\hline & & 30 & & & & 13.2 & 38.2 \\
\hline & 37 & 5 & $41^{\circ} 16.53$ & $05^{\circ} 13.20$ & 13 March 2003 & 13.3 & 38.1 \\
\hline & & 20 & & & & 13.2 & 38.1 \\
\hline & & 50 & & & & 13.0 & 38.3 \\
\hline & 42 & 5 & $41^{\circ} 45.03$ & $05^{\circ} 38.65$ & 17 March 2003 & 13.2 & 38.1 \\
\hline & & 20 & & & & 13.2 & 38.1 \\
\hline & & 70 & & & & 12.9 & 38.3 \\
\hline & 44 & 0 & $41^{\circ} 47.44$ & $05^{\circ} 42.04$ & 17 March 2003 & 13.4 & 38.1 \\
\hline & 47 & 0 & $42^{\circ} 14.98$ & $05^{\circ} 45.01$ & 18 March 2003 & nd & nd \\
\hline & 52 & 5 & $42^{\circ} 14.87$ & $05^{\circ} 14.95$ & 18 March 2003 & 13.0 & 38.4 \\
\hline & & 15 & & & & 13.0 & 38.4 \\
\hline & & 25 & & & & 13.0 & 38.4 \\
\hline & 61 & 5 & $42^{\circ} 13.54$ & $05^{\circ} 07.09$ & 19 March 2003 & 13.3 & 38.4 \\
\hline & & 15 & & & & 13.0 & 38.4 \\
\hline & & 50 & & & & 13.0 & 38.4 \\
\hline & 67 & 5 & $42^{\circ} 16.51$ & $05^{\circ} 00.23$ & 20 March 2003 & 13.1 & 38.4 \\
\hline & & 15 & & & & 13.1 & 38.4 \\
\hline & & 70 & & & & 13.1 & 38.5 \\
\hline & 68 & 0 & $42^{\circ} 22.03$ & $05^{\circ} 01.46$ & 20 March 2003 & nd & nd \\
\hline & 81 & 5 & $42^{\circ} 11.61$ & $04^{\circ} 47.32$ & 21 March 2003 & 13.2 & 38.5 \\
\hline & & 25 & & & & 13.1 & 38.5 \\
\hline & 89 & 0 & $42^{\circ} 30.00$ & $05^{\circ} 00.00$ & 23 March 2003 & nd & nd \\
\hline & 95 & 0 & $41^{\circ} 00.00$ & $04^{\circ} 30.00$ & 24 March 2003 & nd & nd \\
\hline \multirow[t]{5}{*}{ NB5 } & 01 & 0 & $40^{\circ} 44.98$ & $05^{\circ} 00.00$ & 18 April 2003 & nd & nd \\
\hline & 04 & 0 & $42^{\circ} 16.66$ & $05^{\circ} 00.04$ & 21 April 2003 & 14.0 & 38.2 \\
\hline & & 30 & & & & 13.3 & 38.3 \\
\hline & 11 & 0 & $42^{\circ} 17.12$ & $05^{\circ} 02.96$ & 22 April 2003 & 14.2 & 38.2 \\
\hline & & 20 & & & & 13.6 & 38.2 \\
\hline
\end{tabular}


(Table 1 continued)

\begin{tabular}{|c|c|c|c|c|c|c|c|}
\hline Cruise & Station & $\begin{array}{l}\text { Depth } \\
\text { (m) }\end{array}$ & $\begin{array}{l}\text { Latitude } \\
\text { North }\end{array}$ & $\begin{array}{l}\text { Longitude } \\
\text { East }\end{array}$ & Date & $\begin{array}{l}\text { Temperature } \\
\left({ }^{\circ} \mathrm{C}\right)\end{array}$ & Salinity \\
\hline & \multirow[t]{3}{*}{23} & 0 & \multirow[t]{3}{*}{$42^{\circ} 17.53$} & \multirow[t]{3}{*}{$05^{\circ} 05.30$} & \multirow[t]{3}{*}{23 April 2003} & 15.0 & 38.2 \\
\hline & & 25 & & & & 13.9 & 38.2 \\
\hline & & 50 & & & & 13.3 & 38.3 \\
\hline & \multirow[t]{3}{*}{33} & 0 & \multirow[t]{3}{*}{$42^{\circ} 17.29$} & \multirow[t]{3}{*}{$05^{\circ} 05.89$} & \multirow[t]{3}{*}{24 April 2003} & 15.4 & 38.1 \\
\hline & & 30 & & & & 13.4 & 38.2 \\
\hline & & 50 & & & & 13.3 & 38.2 \\
\hline
\end{tabular}

nd, no data.

Thirty-seven formaldehyde-preserved and dilution culture samples were observed using transmission (TEM) and scanning (SEM) electron microscopy. For the examination of diatoms in TEM, samples were treated with nitric and sulphuric acids $\left(1: 1: 4\right.$, sample: $\left.\mathrm{HNO}_{3}: \mathrm{H}_{2} \mathrm{SO}_{4}\right)$, boiled for some seconds in order to remove the organic matter and washed with distilled water. Acid-cleaned material was mounted on Formvar-coated grids. For phytoflagellate identification, one drop of the sample was placed on a 200-mesh copper grid and fixed with $2 \%$ osmium tetroxide vapors. The grid was rinsed in distilled water for a few minutes, air-dried, then stained with uranyl acetate $(0.5 \%)$ for $1 \mathrm{~min}$, rinsed in distilled water and air-dried. All grids were observed with a Philips 400 TEM (Philips Electron Optics BV, Eindhoven, Netherlands). For SEM observations, formaldehyde-preserved samples were placed on $3 \mu \mathrm{m}$-pore size nucleopore filters, washed in distilled water, dehydrated in an ethanol series $(25 \%, 50 \%$, $75 \%, 95 \%$ and $100 \%$ ) and critical point-dried. Dried filters were mounted on stubs, sputter-coated with gold-palladium and observed using a Philips 505 SEM (Philips Electron Optics BV). For phytoflagellate identification, a variable amount, depending on cell concentration, from dilution cultures was fixed with osmium tetroxide ( $1 \%$ final concentration) and processed as above. Some acid-cleaned material was also directly mounted on stub and processed as above for SEM examination.

Suprageneric classification of phytoplankton follows Round et al. (1990) for diatoms, Fensome et al. (1993) for dinoflagellates, Throndsen (1997) for phytoflagellates, and Young et al. (2003) and Silva et al. (2007) for coccolithophores. The main texts used for the identification included Hasle and Syvertsen (1997), Cros and Fortuño (2002) and other specific literature mentioned in the species descriptions provided in the results.

\section{Results}

A total of 168 phytoplankton taxa was collected from the Liguro-Provençal basin of the Mediterranean Sea, comprising 73 Coscinodiscophyceae (34 genera), 47 Dinophyceae (22 genera), 25 Coccolithophyceae (18 genera), 4 Prymnesiophyceae (4 genera), 5 Prasinophyceae (5 genera), 3 Chrysophyceae (3 genera), 2 Cryptophyceae (2 genera), 2 Dictyochophyceae (1 genus), 1 Euglenophyceae, 1 Pelagophyceae, 1 Choanoflagellidea, 1 Filosea, and 3 incertae sedis (Table 2). The last three groups, along with a number of dinoflagellates, are unequivocally heterotrophic. However, we included them as they are generally identified in phytoplankton studies.

The following section includes brief taxonomic descriptions for 25 phytoplankton species recorded from the LiguroProvençal basin (Table 3), along with SEM and/or TEM micrographs and, in some cases, with LM, as well as biogeographic information. The species were selected either because they have never been recorded before in the Mediterranean Sea or were undetected during routine LM observations of field material because they were small and fragile. Description and diagnostic characters for these species are mainly taken from the literature, but in some cases are updated with new observations. The morphometric data are from our own observations.

\section{Coscinodiscophyceae}

\section{Arcocellulus cornucervis Hasle, von Stosch et Syvertsen 1983 (Figures 2, 3)}

References Hasle et al. 1983, p. 59, figs. 11, 301-333, 408-414; Hasle and Syvertsen 1997, p. 179, pl. 36; BérardTherriault et al. 1999, p. 33, pl. 18f-g.

Morphometric data Apical axis: 3.5-8.7 $\mu \mathrm{m}$; pervalvar axis: $1.5 \mu \mathrm{m}$; transapical axis: $0.45 \mu \mathrm{m}$; pervalvar to apical axis ratio: $0.17-0.43$.

Taxonomic description Cells are slightly curved in girdle view and heterovalvate, with a process valve and a pili valve. The pili valve has two ocelluli from which the pili emerge. The pili do not cross each other and may be missing in small cells (Figure 2). Both valves are lanceolate and ornamented with distinct, very small costae which are only present in the central part of the valve (Figure 3, arrow). The arrangement of the pili, valve ornamentation and curvature, and the pervalvar to apical axis ratio are the main characters used for species identification.

Notes In natural material, the pili are not always visible and the cells can be misidentified as bacteria due to their diminutive size and irregular outline.

Distribution This is the first record of Arcocellulus cornucervis in the Mediterranean Sea. The species is usually found in cold-temperate waters, including Helgoland and 
Table 2 List of phytoplankton species recorded in the LiguroProvençal basin, northwestern Mediterranean Sea in spring of 2000 and 2003.

Class: Coscinodiscophyceae Round et Crawford

Subclass: Thalassiosirophycidae Round et Crawford

Order: Thalassiosirales Glezer et Makarova

Family: Thalassiosiraceae Lebour

Genus Thalassiosira Cleve

Thalassiosira cf. allenii Takano

T. eccentrica (Ehrenberg) Cleve

T. mediterranea (Schröder) Hasle

T. profunda (Hendey) Hasle

T. rotula Meunier

T. tenera Proschkina-Lavrenko

Thalassiosira sp. 1

Genus Minidiscus Hasle

Minidiscus comicus Takano

M. trioculatus (Taylor) Hasle

Family: Skeletonemataceae Lebour emend. Round et Crawford

Genus Skeletonema Greville

Skeletonema cf. dohrnii Sarno et Kooistra

Genus Detonula Schütt ex De Toni

Detonula pumila (Castracane) Gran

Family: Stephanodiscaceae Glezer et Makarova

Genus Cyclotella (Kützing) Brébisson

Cyclotella choctawhatcheeana Prasad

Subclass: Coscinodiscophycidae Round et Crawford

Order: Coscinodiscales Round et Crawford

Family: Coscinodiscaceae Kützing emend. Round et Crawford

Genus Coscinodiscus Ehrenberg emend. Hasle et $\mathrm{Sims}$

Coscinodiscus spp.

Family: Hemidiscaceae Hendey emend. Simonsen

Genus Hemidiscus Wallich

Hemidiscus cuneiformis Wallich

Order: Asterolamprales Round et Crawford

Family: Asterolampraceae H.L. Smith

Genus Asteromphalus Ehrenberg

Asteromphalus cf. parvulus Karsten

Subclass: Biddulphiophycidae Round et Crawford

Order: Hemiaulales Round et Crawford

Family: Hemiaulaceae Heiberg

Genus Cerataulina H. Peragallo ex Schütt Cerataulina pelagica (Cleve) Hendey

Genus Eucampia Ehrenberg

Eucampia cornuta (Cleve) Grunow

E. zodiacus Ehrenberg

Genus Hemiaulus Ehrenberg

Hemiaulus hauckii Grunow

Subclass: Lithodesmiophycidae Round et Crawford

Order: Lithodesmiales Round et Crawford

Family: Lithodesmiaceae Round

Genus Ditylum J.W. Bailey ex L.W. Bailey Ditylum brightwellii (T. West) Grunow

Subclass: Corethrophycidae Round et Crawford

Order: Corethrales Round et Crawford

Family: Corethraceae Lebour

Genus Corethron Castracane

Corethron hystrix Hensen

ER

ER

VR

$\mathrm{ER}^{\mathrm{a}}$

$\mathrm{R}$

ER

ER

$\mathrm{A}^{\mathrm{b}}$

ER

F

VR

ER

F
(Table 2 continued)

Subclass: Cymatosirophycidae Round et Crawford

Order: Cymatosirales Round et Crawford

Family: Cymatosiraceae Hasle, von Stosch et Syvertsen

Genus Arcocellulus Hasle, von Stosch et

Syvertsen

Arcocellulus cornucervis Hasle, von Stosch et $\quad \mathrm{A}^{\mathrm{a}}$

Syvertsen

A. mammifer Hasle, von Stosch et Syvertsen

Genus Papiliocellulus Hasle, von Stosch et

Syvertsen

Papiliocellulus simplex Gardner et Crawford

$\mathrm{ER}^{\mathrm{a}}$

Subclass: Rhizosoleniophycidae Round et Crawford

Order: Rhizosoleniales Silva

Family: Rhizosoleniaceae De Toni

Genus Rhizosolenia Ehrenberg emend. Brightwell Rhizosolenia imbricata Brightwell

Genus Proboscia Sundström

Proboscia alata (Brightwell) Sundström

Genus Guinardia H. Peragallo

Guinardia flaccida (Castracane) H. Peragallo VR

G. striata (Stolterfoth) Hasle

Genus Dactyliosolen Castracane

Dactyliosolen fragilissimus (Bergon) Hasle

D. phuketensis (Sundström) Hasle

$\mathrm{A}^{\mathrm{a}}$

$\mathrm{A}^{\mathrm{a}}$

Genus Neocalyptrella (Norman) Hernández-

Becerril et Meave del Castillo

Neocalyptrella robusta (Norman) Hernández-

Becerril et Meave del Castillo

Subclass: Chaetocerotophycidae Round et Crawford

Order: Chaetocerotales Round et Crawford

Family: Chaetocerotaceae Ralfs

Genus Bacteriastrum Shadbolt

Bacteriastrum comosum Pavillard

B. furcatum Shadbolt

VR

Genus Chaetoceros Ehrenberg

Chaetoceros affinis Lauder

C. brevis Schütt

C. cf. convolutus Castracane

C. constrictus Gran

C. contortus Schütt

C. costatus Pavillard

C. curvisetus Cleve

C. danicus Cleve

C. decipiens Cleve

C. diadema (Ehrenberg) Gran

C. diversus Cleve

C. lauderi Ralfs

C. lorenzianus Grunow

C. messanensis Castracane

C. peruvianus Brightwell

C. protuberans Lauder

C. pseudocurvisetus Mangin

C. tenuissimus Meunier

C. teres Cleve

Chaetoceros spp.

$\mathrm{R}$

VR

F

F

F

VR

A

F

VR

$\mathrm{F}$

$\mathrm{F}$

A

$\mathrm{R}$

A

VR

F

F

F

$\mathrm{R}$

$\mathrm{F}$

VR

VR

F

$\mathrm{R}$

VR

F

A

Order: Leptocylindrales Round et Crawford

Family: Leptocylindraceae Lebour

Genus Leptocylindrus Cleve

Leptocylindrus danicus Cleve

L. mediterraneus (H. Peragallo) Hasle
A

F 
(Table 2 continued)

Class: Fragilariophyceae Round

Subclass: Fragilariophycidae Round

Order: Fragilariales Silva emend. Round

Family: Fragilariaceae Greville

Genus Asterionellopsis Round

Asterionellopsis glacialis (Castracane) Round A

Order: Thalassionematales Round

Family: Thalassionemataceae Round

Genus Thalassionema Grunow

Thalassionema spp.

Genus Lioloma Hasle

Lioloma sp. 1

Class: Bacillariophyceae Haeckel emend. Mann

Subclass: Bacillariophycidae Mann

Order: Achnanthales Silva

Family: Cocconeidaceae Kützing

Genus Cocconeis Ehrenberg

Cocconeis fasciolata (Ehrenberg) Brown

Order: Naviculales Bessey emend. Mann

Suborder: Naviculineae Hendey

Family: Naviculaceae Kützing

Genus Navicula Bory emend. Cox

Navicula sp. 1

Genus Nitzschia Hassall
Navicula sp. 2

Genus Haslea Simonsen

Haslea wawrickae (Hustedt) Simonsen

Family: Pleurosigmataceae Mereschkowsky

Genus Pleurosigma W. Smith

Pleurosigma spp.

Family: Plagiotropidaceae Mann

Genus Plagiotropis Pfitzer

Plagiotropis lepidoptera (Gregory) Kuntze

Order: Bacillariales Hendey emend. Mann

Family Bacillariaceae Ehrenberg

Genus Pseudo-nitzschia H. Peragallo

Pseudo-nitzschia calliantha Lundholm,

Moestrup et Hasle

P. delicatissima group

P. fraudulenta (Cleve) Hasle

$P$. galaxiae Lundholm et Moestrup

P. multistriata (Takano) Takano

Nitzschia longissima (Brébisson) Ralfs

Nitzschia spp.

Genus Cylindrotheca Rabenhorst

Cylindrotheca closterium (Ehrenberg) Reimann et Lewin

Genus Psammodictyon Mann

Psammodictyon panduriforme (Gregory) Mann

ER

ER

VR

VR

VR

F

F

A

F

VR

VR

VR

F

ER

Class: Dinophyceae Pascher

Subclass: Gymnodiniphycidae Fensome, Taylor, Norris,

Sarjeant, Wharton et Williams

Order: Gymnodiniales Apstein

Suborder: Gymnodiniineae Fensome, Taylor, Norris,

Sarjeant, Wharton et Williams

Family: Gymnodiniaceae (Bergh) Lankester

Genus Gymnodinium Stein

Gymnodinium spp.

Genus Amphidinium Claparède et Lachmann Amphidinium sp. 1

Genus Cochlodinium Schütt

Cochlodinium sp. 1
(Table 2 continued)

Genus Gyrodinium Kofoid et Swezy

Gyrodinium fusiforme Kofoid et Swezy

G. cf. pingue (Schütt) Kofoid et Swezy

Gyrodinium spp.

Genus Torodinium Kofoid et Swezy

Family: Warnowiaceae Lindemann

Genus Warnovia Lindemann

Warnovia sp. 1

Order: Ptychodiscales Fensome, Taylor, Norris,

Sarjeant, Wharton et Williams

Family: Amphitholaceae Poche

Genus Achradina Lohmann

$$
\text { Achradina pulchra Lohmann }
$$

VR

Subclass: Peridiniphycidae Fensome, Taylor, Norris,

Sarjeant, Wharton et Williams

Order: Gonyaulacales Taylor

Suborder Cladopyxiineae Fensome, Taylor, Norris,

Sarjeant, Wharton et Williams

Family: Cladopyxiaceae Stein

Genus Amphidoma Stein

Amphidoma caudata Halldal

Genus Micracanthodinium Deflandre

Micracanthodinium spp.

Suborder: Gonyaulacineae Fensome, Taylor, Norris,

Sarjeant, Wharton et Williams

Family: Gonyaulacaceae Lindemann

Subfamily: Gonyaulacoideae Fensome, Taylor,

Norris, Sarjeant, Wharton et Williams

Genus Gonyaulax Diesing

Gonyaulax polygramma Stein

Suborder: Ceratiineae Fensome, Taylor, Norris,

Sarjeant, Wharton et Williams

Family: Ceratiaceae Willey et Hickson

Genus Neoceratium Gómez, Moreira et López-

Garcia

Neoceratium candelabrum (Ehrenberg)

Gómez, Moreira et López-Garcia

N. euarcuatum (Jørgensen) Gómez,

Moreira et López-Garcia

N. furca (Ehrenberg) Gómez, Moreira et

López-Garcia

N. fusus (Ehrenberg) Gómez, Moreira et

López-Garcia

N. horridum (Gran) Gómez, Moreira et

López-Garcia

N. pentagonum (Gourret) Gómez et López-

Garcia

N. symmetricum (Pavillard) Gómez,

Moreira et López-Garcia

$N$. teres (Kofoid) Gómez, Moreira et

López-Garcia

N. tripos (O.F. Müller) Gómez, Moreira et

López-Garcia

$\mathrm{R}$

VR

ER

ER

VR

VR

VR

VR

VR

ER

VR

VR

Suborder: Goniodomineae Fensome, Taylor, Norris,

Sarjeant, Wharton et Williams

Family: Goniodomaceae Lindemann

Subfamily: Goniodomoideae Fensome, Taylor,

Norris, Sarjeant, Wharton et Williams

Genus Goniodoma Stein

Goniodoma polyedricum (Pouchet)

VR
Torodinium robustum Kofoid et Swezy

Order: Peridiniales Haeckel
VR

VR

VR

ER

$\mathrm{R}$

R

R


(Table 2 continued)

Suborder: Heterocapsineae Fensome, Taylor, Norris,

Sarjeant, Wharton et Williams

Family: Heterocapsaceae Fensome, Taylor, Norris,

Sarjeant, Wharton et Williams

Genus Heterocapsa Stein

Heterocapsa minima Pomroy

Suborder: Peridiniineae Fensome, Taylor, Norris,

Sarjeant, Wharton et Williams

Family: Peridiniaceae Ehrenberg

Subfamily: Calciodinelloideae Fensome, Taylor,

Norris, Sarjeant, Wharton et Williams

Genus Scrippsiella Balech ex Loeblich III Scrippsiella sp. 1

Family: Congruentidiaceae Schiller

Subfamily: Congruentidioideae Fensome,

Taylor, Norris, Sarjeant, Wharton et Williams

Genus Protoperidinium: P. cf. brachypus sensu

Abé

Protoperidinium americanum (Gran et

Braarud) Balech

P. bipes (Paulsen) Balech

P. cf. brachypus sensu Abé

P. depressum (Bailey) Balech

P. oceanicum (Vanhöffen) Balech

P. steinii (Jørgensen) Balech

Subfamily: Diplopsalidioideae Abé

Genus Diplopsalis Bergh

Diplopsalis spp.

Genus Preperidinium Mangin

Preperidinium meunieri (Pavillard)

Elbrächter

Order: Uncertain

Family: Oxytoxaceae Lindemann

Genus Oxytoxum Stein

Oxytoxum cf. caudatum Schiller

O. longiceps Schiller

O. scolopax Stein

O. variabile Schiller

$\mathrm{VR}^{\mathrm{a}}$

ER

ER

F

ER

VR

ER

ER

VR

ER

VR

ER

VR

$\mathrm{R}$

Subclass: Dinophysiphycidae Mohn ex Fensome, Taylor, Norris, Sarjeant, Wharton et Williams

Order: Dinophysiales Kofoid

Family: Dinophysiaceae Stein

Genus Dinophysis Ehrenberg

Dinophysis caudata Saville-Kent

D. cf. punctata Jörgensen

D. tripos Gourret

ER

ER

ER

Subclass: Prorocentrophycidae Fensome, Taylor, Norris,

Sarjeant, Wharton et Williams

Order: Prorocentrales Lemmermann

Family: Prorocentraceae Stein

Genus Mesoporos Lillick

Mesoporos perforatus (Gran) Lillick

Genus Prorocentrum Ehrenberg

Prorocentrum balticum (Lohmann) Loeblich III ER

P. compressum (Bailey) Abé ex Dodge VR

$P$. dentatum Stein ER

P. donghaiense $\mathrm{Lu} \quad \mathrm{VR}^{\mathrm{a}}$

P. micans Ehrenberg VR

P. triestinum Schiller ER

Subclass: Incertae Sedis

Order: Thoracosphaerales Tangen

Family: Thoracosphaeraceae Schiller
(Table 2 continued)

Genus Thoracosphaera Kamptner

Thoracosphaera heimii (Lohmann) Kamptner

VR

Class: Cryptophyceae Fritsch

Order: Cryptomonadales Engler

Family: Cryptomonadaceae Ehrenberg

Genus Plagioselmis Butcher ex Hill

Plagioselmis prolonga Butcher ex Novarino,

ER

Lucas et Morrall

Genus Teleaulax Hill

Teleaulax acuta (Butcher) Hill

ER

Class: Crysophyceae Christensen

Order: Ochromonadales Pascher

Family: Chrysococcaceae Lemmermann

Genus Ollicola Vørs

Ollicola vangoorii (Conrad) Vørs

Family: Dinobryaceae Ehrenberg

Genus Dinobryon Ehrenberg

Dinobryon faculiferum (Willén) Willén

Order: Chrysosphaerales Bourrelly

Family: Aurosphaeraceae Schiller

Genus Meringosphaera Lohmann

Meringosphaera mediterranea Lohmann

VR

Class: Dictyochophyceae Silva

Order: Dictyochales Haeckel

Family: Dictyochaceae Lemmermann

Genus Dictyocha Ehrenberg

Dictyocha fibula Ehrenberg

D. speculum Ehrenberg

F

VR

Class: Coccolithophyceae Rothmaler

Order: Isochrysidales Pascher

Family: Noelaerhabdaceae Jerkovic emend. Young et

Bown

Genus Emiliania Hay et Mohler

Emiliania huxleyi (Lohmann) Hay et Mohler

Genus Gephyrocapsa Kamptner

Gephyrocapsa muellerae Bréhéret

A

Order: Coccolithales Schwarz emend. Edvarsen et

Eikrem

Family: Calcidiscaceae Young et Bown

Genus Calcidiscus Kamptner

Calcidiscus leptoporus (Murray et Blackman)

Loeblich et Tappan

Genus Umbilicosphaera Lohmann

Umbilicosphaera foliosa (Kamptner ex Kleijne) ER

Geisen

U. sibogae (Weber-van Bosse) Gaarder

$\mathrm{R}$

Order: Zygodiscales Young et Bown

Family: Helicosphaeraceae Black emend. Jafar et

Martini

Genus Helicosphaera Kamptner

Helicosphaera carterii (Wallich) Kamptner

Family: Pontosphaeraceae Lemmermann

Genus Pontosphaera Lohmann Pontosphaera discopora Schiller

P. syracusana Lohmann

$\mathrm{R}$

VR

ER

Genus Scyphosphaera Lohmann

Scyphosphaera apsteinii Lohmann

Family: Calyptrosphaeraceae Boudreaux et Hay

Genus Anthosphaera Kamptner emend. Kleijne Anthosphaera sp. type B sensu Cros and

Fortuño
$\mathrm{R}$

VR

VR

VR

ER

ER 
(Table 2 continued)

Genus Sphaerocalyptra Deflandre

Sphaerocalyptra quadridentata (Schiller)

Deflandre

Genus Poritectolithus Kleijne

Poritectolithus poritectus (Heimdal) Kleijne

Order: Syracosphaerales Hay emend. Young, Geisen,

Cros, Kleijne, Sprengel, Probert et Østergaard

Family: Syracosphaeraceae (Lohmann) Lemmermann

Genus Ophiaster Gran emend. Manton et Oates

Ophiaster spp.

Genus Syracosphaera Lohmann

Syracosphaera corolla Lecal

S. didyma Kleijne et Cros

S. marginaporata Knappertsbusch

S. molischii Schiller type 2

S. prolongata Gran ex Lohmann type 2 sensu

Heimdal et Gaarder

S. pulchra Lohmann

Family: Calciosoleniaceae Kamptner

Genus Calciosolenia Gran emend. Young, Geisen,

Cros, Kleijne, Sprengel, Probert et Østergaard Calciosolenia murrayi Gran

Family: Rhabdosphaeraceae Haeckel

Genus Rhabdosphaera Haeckel

Rhabdosphaera clavigera Murray et Blackman

Genus Discosphaera Haeckel

Discosphaera tubifera (Murray et Blackman) Ostenfeld

Genus Acanthoica Lohmann emend. Schiller et

Kleijne

Acanthoica quattrospina Lohmann

Genus Algirosphaera Schlauder emend. Norris Algirosphaera robusta (Lohmann) Norris

Family: Papposphaeraceae Jordan et Young

Genus Papposphaera Tangen

Papposphaera lepida Tangen

Class: Prymnesiophyceae Hibberd

Order: Prymnesiales Papenfuss emend. Edvardsen $e t$ Eikrem

Family: Prymnesiaceae Conrad ex Schmidt

Genus Chrysochromulina Lackey

Chrysochromulina kappa Parke et Manton

Genus Hyalolithus Yoshida, Noël, Nakayama,

Naganuma et Inouye

Hyalolithus neolepis Yoshida, Noël, Nakayama, ER

Naganuma et Inouye

Genus Imantonia Reynolds

Imantonia rotunda Reynolds

Order: Phaeocystales Medlin

Family: Phaeocystaceae Lagerheim

Genus Phaeocystis Lagerheim

Phaeocystis sp. 3 sensu Medlin et Zingone

F

Class: Euglenophyceae Schenichen

Order: Euglenales Engler

Family: Eutreptiaceae Hollande

Genus Eutreptiella de Cuhna

Eutreptiella spp.

ER

Class: Prasinophyceae Moestrup et Throndsen

Order: Mamiellales Moestrup

Family: Mamiellaceae Moestrup

Genus Mantoniella Desikachary

Mantoniella squamata (Manton et Parke)

VR

ER

ER
Syvertsen 1983 (Figures 4-7)

Reference Hasle et al. 1983, p. 55, figs. 10, 272-300, 415-421.

Morphometric data Apical axis: 2.9-5.8 $\mu \mathrm{m}$; pervalvar axis: 1.6-4.0 $\mu \mathrm{m}$; transapical axis: $1.0-1.3 \mu \mathrm{m}$; pervalvar to apical axis ratio: $0.3-0.7$.

Taxonomic description Cells are markedly curved in girdle view with pili crossing each other (Figures 4 and 5).

(Table 2 continued)

Family: Chlorodendraceae Oltmanns

Manton

Genus Tetraselmis Stein

Tetraselmis spp.

ER

Schmarda

F

Genus Micromonas Manton et Parke

Class: Pelagophyceae Andersen et Saunders

Order: Pelagomonadales Andersen et Saunders

Genus Pelagomonas Andersen et Saunders

Pelagomonas calceolata Andersen et Saunders $\quad \mathrm{ER}^{\mathrm{a}}$

lass: Choanoflagellidea Kent

Genus Parvicorbicula (Meunier) Deflandre

Parvicorbicula socialis (Meunier) Deflandre

A

Family: Paulinellidae de Saedeleer

Genus Paulinella Page

Paulinella ovalis (Wulff) Johnson, Hargraves et ER Sieburth

Genus Commation Thomsen et Larsen

Commation cryoporinum The
Genucocryptos Butcher

Leucocryptos marina (Braarud) Butcher

$\mathrm{R}$

Rhizomonas setigera (Pavillard) Patterson, Nygaard, Steinberg et Turley

$\mathrm{F}$

A, abundant $\left(>10^{5}\right.$ cells $\left.1^{-1}\right) ; \mathrm{F}$, frequent $\left(10^{4}-10^{5}\right.$ cells $\left.1^{-1}\right)$; $\mathrm{R}$, rare $\left(<10^{4}\right.$ cells $\left.1^{-1}\right)$; VR, very rare $\left(<5 \times 10^{3}\right.$ cells $\left.1^{-1}\right)$; ER, extremely rare, only observed in electron microscopy or serial dilution culture; andicates first occurrence in Mediterranean Sea; bindicates first occurrence in northwestern Mediterranean Sea.

Bremerhaven waters in the German sector of the North Sea (Hasle et al. 1983) and other temperate waters of the northern Eastern Canada (Bérard-Therriault et al. 1999), and from the South Island in New Zealand (Hasle and Syvertsen 1997). 
Table 3 List of 25 illustrated phytoplankton species sampled during the NORBAL (NB) cruises in the northwestern Mediterranean Sea.

\begin{tabular}{|c|c|c|c|c|c|c|c|}
\hline Species & Cruise & Station & NS & SDC & NET & LM & EM \\
\hline \multicolumn{8}{|l|}{ Coscinodiscophyceae } \\
\hline Arcocellulus cornucervis & NB1 & 44,53 & $x$ & & & $x$ & $x$ \\
\hline \multirow[t]{2}{*}{ A. mammifer } & NB4 & $\begin{array}{l}04,10,13,15,18,19,21 \\
28,31,37,42,52,61,67\end{array}$ & $x$ & $x$ & & $x$ & $x$ \\
\hline & NB5 & 04 & $x$ & & & & $x$ \\
\hline \multirow[t]{2}{*}{ Minidiscus comicus } & NB4 & $04,10,28,47$ & $x$ & $x$ & & $x$ & $x$ \\
\hline & NB5 & 01,33 & $\times$ & $\times$ & & $\times$ & $x$ \\
\hline \multirow[t]{2}{*}{ M. trioculatus } & NB1 & 47 & $x$ & & & & $x$ \\
\hline & NB4 & 28,37 & & $\times$ & & $\times$ & $x$ \\
\hline Papiliocellulus simplex & NB4 & 28,37 & & $\times$ & & $\times$ & $x$ \\
\hline Thalassiosira profunda & NB4 & 10,28 & & $\times$ & & $\times$ & $\times$ \\
\hline T. tenera & NB4 & 44,52 & & $x$ & $x$ & & $\times$ \\
\hline \multicolumn{8}{|l|}{ Dinophyceae } \\
\hline Heterocapsa minima & NB4 & 13,31 & $x$ & & & & $x$ \\
\hline Prorocentrum donghaiense & NB4 & 13 & $\times$ & & & & $x$ \\
\hline Protoperidinium americanum & NB4 & 52 & & & $x$ & & $x$ \\
\hline P. cf. brachypus & NB4 & 52 & & & $\times$ & & $\times$ \\
\hline \multicolumn{8}{|l|}{ Coccolithophyceae } \\
\hline Anthosphaera sp. type B & NB1 & 44 & $x$ & & & & $\times$ \\
\hline \multirow[t]{2}{*}{ Gephyrocapsa muellerae } & NB1 & 44 & $x$ & & & & $\times$ \\
\hline & NB4 & 31 & $x$ & & & & $\times$ \\
\hline Poritectolithus poritectus & NB4 & 52 & & & $x$ & & $\times$ \\
\hline Syracosphaera corolla & NB1 & 44 & $\times$ & & & & $\times$ \\
\hline S. didyma & NB4 & 13 & $x$ & & & & $x$ \\
\hline S. marginaporata & NB1 & 44 & $x$ & & & & $\times$ \\
\hline S. molischii type 2 & NB1 & 44 & $x$ & & & & $\times$ \\
\hline S. prolongata & NB4 & 13,52 & $x$ & & $\times$ & & $\times$ \\
\hline Umbilicosphaera foliosa & NB4 & 52 & & & $x$ & & $\times$ \\
\hline \multicolumn{8}{|l|}{ Prymnesiophyceae } \\
\hline \multirow[t]{2}{*}{ Chrysochromulina kappa } & NB4 & $01,14,28$ & & $\times$ & & $\times$ & $x$ \\
\hline & NB5 & 01 & & $\times$ & & $x$ & $x$ \\
\hline Hyalolithus neolepis & NB4 & $13,31,44,68,89,95$ & $x$ & & & $\times$ & $x$ \\
\hline Phaeocystis sp. 3 & NB4 & 01 & & $\times$ & & $\times$ & $\times$ \\
\hline \multicolumn{8}{|l|}{ Cryptophyceae } \\
\hline Plagioselmis prolonga & NB4 & 44 & $x$ & & & $x$ & $\times$ \\
\hline Teleaulax acuta & NB4 & 44 & $x$ & & & $\times$ & $x$ \\
\hline
\end{tabular}

NS, natural sample; SDC, serial dilution culture; NET, net sample; LM, light microscopy; EM, electron microscopy.

In EM, small spines (spinules) are visible in the terminal part of the pili (Figure 7). Valves are oblong to circular. They have a velum which has irregularly shaped perforations of different size (ricoida velum) (Figure 6). This velum is a constant character helping the identification of the species, particularly when it loses the typical shape and pili. This species usually occurs as solitary cells or in pairs. In old cultures, cells appear nearly rectangular, without pili and may form long chains of more than 10 cells, joined to each other by the valvar face. The species can be distinguished from the congeneric Arcocellulus cornucervis by the presence of the velum, by the more pronounced valve curvature, pili that cross each other and the larger pervalvar axis.

Distribution This is the first record of Arcocellulus mammifer in the Mediterranean Sea. The species has been recorded in plankton and benthos samples from cold-temperate waters of Helgoland and Bremerhaven in the German sector of the North Sea, and in subtropical coastal waters of the Gulf of Mexico (Hasle et al. 1983).

\section{Minidiscus comicus Takano 1981 (Figures 8, 9)}

References Takano 1981, p. 32, figs. 1a, 2-13; BérardTherriault et al. 1999, p. 20, pl. 2d; Aké-Castillo et al. 2001, p. 105, figs. 4, 5.

\section{Morphometric data Cell diameter: 2.7-4.3 $\mu \mathrm{m}$.}

Taxonomic description Cells are usually solitary, sometimes in pairs. In culture, cells are often cylindrical in girdle view due to the marked development of cingular bands, and have convex valves (Figure 8), whereas in natural samples they often have a lenticular shape. The circular valve is 


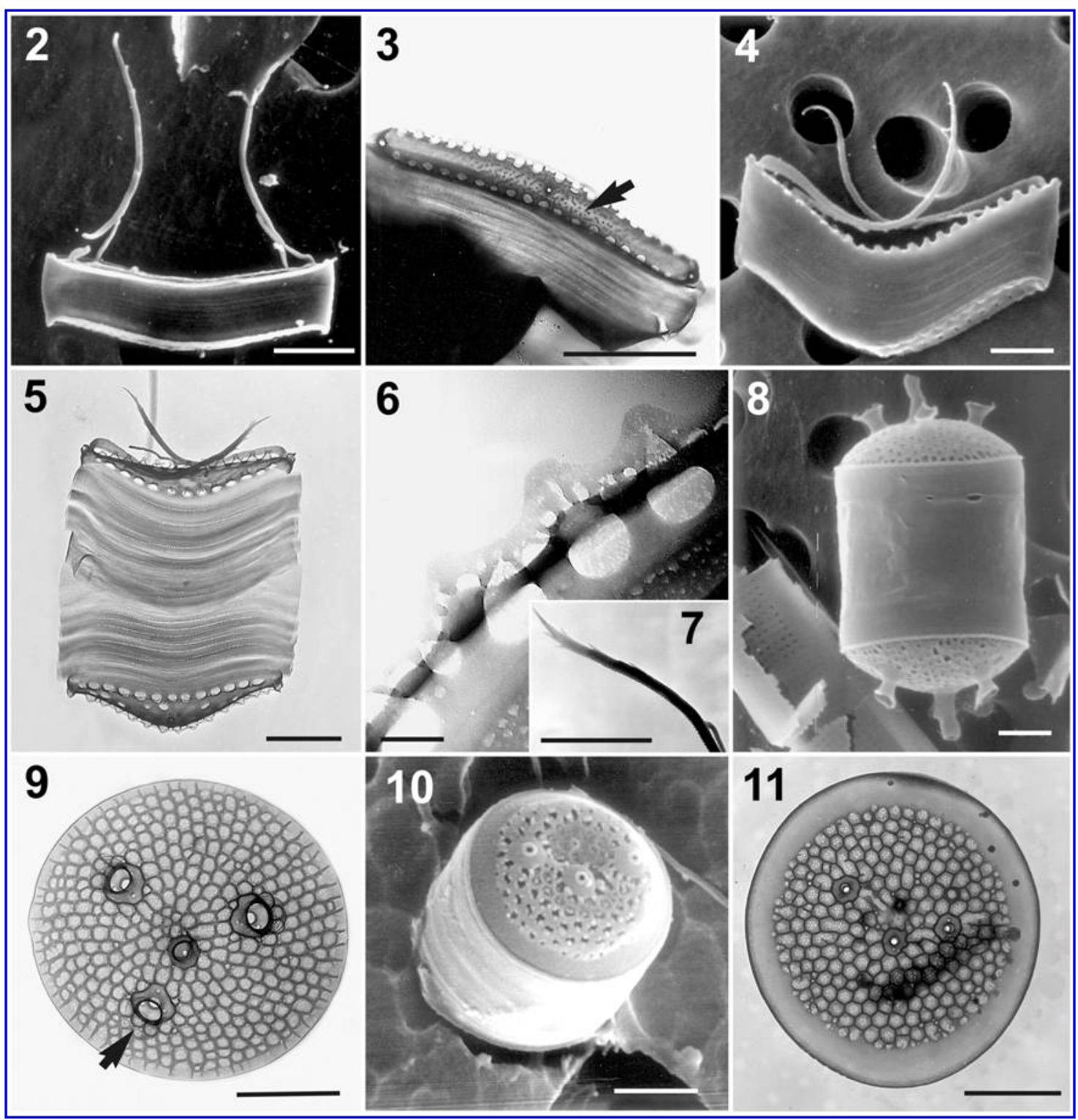

Figures 2-11 Centric diatoms of the Liguro-Provençal basin in the northwestern Mediterranean Sea.

(2) Arcocellulus cornucervis cell in girdle view, natural sample, SEM. (3) A. cornucervis valve in oblique view with wrinkled costae (arrow) and the single process ornamenting the valve, natural sample, TEM. (4) Arcocellulus mammifer cell in girdle view, cultured material, SEM. (5) A. mammifer cell in girdle view, culture material, TEM. (6) A. mammifer areolae showing velum, culture material, TEM. (7) A. mammifer terminal part of pilus, culture material, TEM. (8) Minidiscus comicus cell in girdle view, culture material, SEM. (9) M. comicus cell in valve view showing fultoportulae with three satellite pores (arrow), culture material, TEM. (10) M. trioculatus cell in oblique view, natural sample, SEM. (11) $M$. trioculatus cell in valve view showing a distinct hyaline margin, culture material, TEM. Scale bars $=2 \mu \mathrm{m}$ (Figures 2, 3, 5, 7); $1 \mu \mathrm{m}$ (Figures 4, 8-11); $0.2 \mu \mathrm{m}$ (Figure 6).

slightly convex, with no distinct mantle. Three to four fultoportulae with three satellite pores on each process base are located halfway between the valve center and the margin (Figure 9, arrow). One rimoportula with a long external tube is present at the center of the valve (Figure 9).

Notes A long, straight filament, possibly made of chitin, emerges from one of the processes and runs obliquely with respect to the valve face. This is at times clearly visible also in LM, allowing for the species identification (data not shown).
Distribution The species was described from Japanese waters (Takano 1981) and it was later recorded from the French Atlantic coasts (Chrétiennot-Dinet and Guillocheau 1987), English Channel (Aké-Castillo et al. 2001), Caspian Sea (Genkal and Makarova 1985), Atlantic North American and Argentine waters (Lange 1985), Gulf of St. Lawrence, Eastern Canada (Bérard-Therriault et al. 1999), Gulf of Mexico (Aké-Castillo et al. 2001) and Xiamen, Fujian, China (Gao et al. 1992). In the Mediterranean, it is present in the Adriatic (Hasle and Syvertsen 1997) and Tyrrhenian seas (Ribera d'Alcalà et al. 2004). 


\section{Minidiscus trioculatus (Taylor) Hasle 1973 (Figures $10,11)$ \\ Basionym Coscinodiscus trioculatus Taylor 1967, p. 437, pl. 5, fig. 43.}

References Hasle 1973, p. 29, figs. 101-108; BérardTherriault et al. 1999, p. 20, pl. 2c; Aké-Castillo et al. 2001, p. 105 , figs. $1-3$.

\section{Morphometric data Cell diameter: 2.2-3.9 $\mu \mathrm{m}$.}

Taxonomic description Cells are small in diameter, with relatively flat valves. Each valve has hexagonal areolae and two or three fultoportulae distant from the prominent hyaline margin. Each fultoportula has two satellite pores on its basal part. One small rimoportula is located near the center of the valve and is sometimes associated with one areola different in size and shape from the others (Figures 10, 11). The species can be distinguished from Minidiscus comicus in EM.

Distribution The species is cosmopolitan (Hasle 1973, Bérard-Therriault et al. 1999, Aké-Castillo et al. 2001). In the Mediterranean Sea, it has been recorded from the Tyrrhenian (Giuffré et al. 1991) and Adriatic seas (Hasle and Syvertsen 1997), and along the Catalan coasts (Estrada 1979, Delgado and Fortuño 1991).

\section{Papiliocellulus simplex Gardner et Crawford 1992 (Figures 12-16)}

Reference Gardner and Crawford 1992, p. 247, figs. 1-8.

Morphometric data Apical axis: 3-11 $\mu \mathrm{m}$; pervalvar axis: $7 \mu \mathrm{m}$; transapical axis: $1.5-2.6 \mu \mathrm{m}$.

Taxonomic description Cells are very small and solitary, with one chloroplast (Figure 14). Cells are elliptical in valve view, rectangular in girdle view and heterovalvate. Both valves have a central annulus, whereas only one valve has a central tubular process (Figures 12, 13, 15). An ocellulus with four porelli is present at each apex of both valves (Figure 16). A zigzag interstria runs along the apical axis, departing from the ocelluli and crossing the annulus. The ridge of the valve is not as well-developed as in the congeneric species Papiliocellulus elegans Hasle, von Stosch et Syvertsen (Hasle et al. 1983).

Distribution This is the first record of Papiliocellulus simplex in the Mediterranean Sea. The species has been found previously only in the type locality, i.e., from South Wales and Charmouth, Dorset, England (Gardner and Crawford 1992).

\section{Thalassiosira profunda (Hendey) Hasle 1973 (Figures 17-19)}

Basionym Cylindropyxis profunda Hendey 1964, p. 93, pl. 23, fig. 9.
References Hasle 1972, p. 66, fig. 9; Hasle 1973, p. 31, figs. 98-101; Hallegraeff 1984, p. 499, fig. 13; Aké-Castillo et al. 1999 , p. 45 , pl. 18, figs. 134-135.

Morphometric data Cell diameter: 1.25-2.70 $\mu \mathrm{m}$.

Taxonomic description Cells are extremely small, usually solitary, rarely forming chains of three to four cells connected by a thread. Each valve generally has four marginal fultoportulae, each with four satellite pores, and one to two central fultoportulae with two to three satellite pores (Figure 17). The central fultoportulae are associated with a central areola (Figures 17, 18). One short rimoportula is present between two marginal fultoportulae (Figures 17, 18, arrows). The poroid areolae are often very weakly silicified. They are rectangular in the central part of the valve, becoming elongated toward the margin. The cingulum is comprised of a valvocopula, scattered with minute pores, and several smooth cingular bands (Figure 19).

Distribution This is the first record of Thalassiosira profunda in the Mediterranean Sea. The species has been described from the Bay of Biscay, off the French and Spanish Atlantic coasts (Hendey 1964) and subsequently recorded in the Gulf of Tehuantepec in Mexico (Aké-Castillo et al. 1999), the sub-arctic North Pacific Ocean (Taylor and Waters 1982), and Australian waters (Hasle 1973, Hallegraeff 1984).

\section{Thalassiosira tenera Proschkina-Lavrenko 1961 (Figures 20-22)}

References Proschkina-Lavrenko 1961, p. 33, pl. 1, figs. 1-4, pl. 2, figs. 5-7; Hasle and Fryxell 1977, p. 28, figs. 54-65; Harris et al. 1995, p. 121, figs. 6, 24; Bérard-Therriault et al. 1999, p. 28, pl. 12a-b; Hoppenrath et al. 2009, p. 60 , fig. $25 \mathrm{~g}-1$.

Morphometric data Cell diameter: 11.2-16.3 $\mu \mathrm{m}$; 13-16 areolae in $10 \mu \mathrm{m}$; 4-6 fultoportulae in $10 \mu \mathrm{m}$.

Taxonomic description Cells have a small, flat valve surface, with distinct hexagonal areolae with a circular foramen. A fultoportula is present in the valve center (Figures 20-22). Central and marginal fultoportulae are sometimes covered by a siliceous cap. A rimoportula is located between two marginal fultoportulae (Figure 20, arrow).

Distribution The species is cosmopolitan (Hasle and Fryxell 1977). In the Mediterranean Sea, it has been recorded from the Greek (Hasle and Fryxell 1977) and Turkish coasts (Koray 2001).

\section{Dinophyceae}

Heterocapsa minima Pomroy 1989 (Figures 23, 24)

Reference Pomroy 1989, p. 132, figs. 1-5.

Morphometric data Length: 7.9-10.6 $\mu \mathrm{m}$; width: 5.0-8.3 $\mu \mathrm{m}$. 


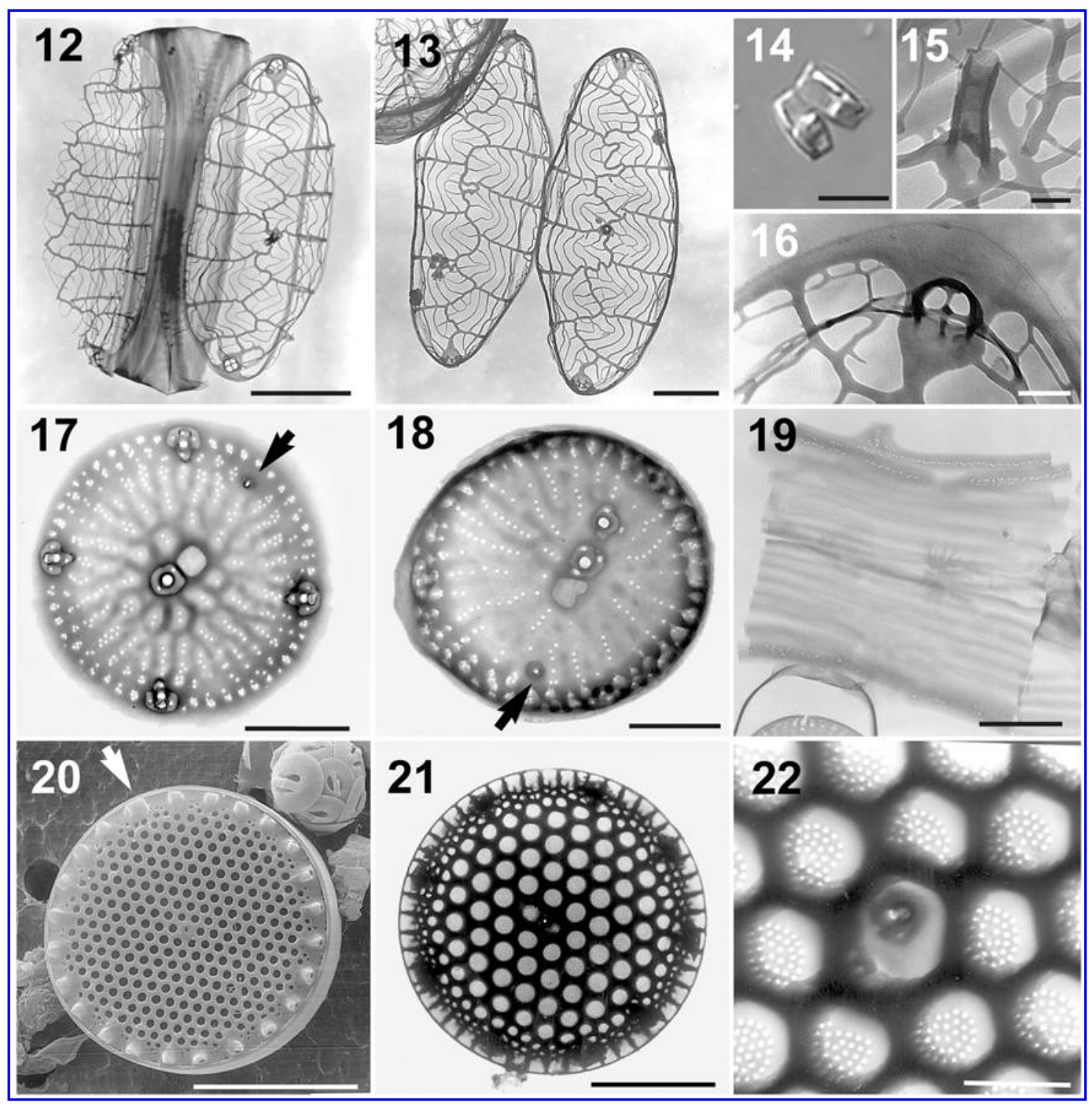

Figures 12-22 Centric diatoms of the Liguro-Provençal basin in the northwestern Mediterranean Sea.

(12) Papiliocellulus simplex valves and cingular bands, cultured material, TEM. (13) P. simplex, two valves, cultured material, TEM. (14) P. simplex two cells in girdle view, cultured material, LM. (15) P. simplex detail of the process valve, cultured material, TEM. (16) P. simplex valve apex with an ocellulus, cultured material, TEM. (17) Thalassiosira profunda valve with one central fultoportula. The arrow points at the rimoportula, cultured material, TEM. (18) T. profunda valve with two central fultoportulae. The arrow points at the rimoportula, cultured material, TEM. (19) T. profunda cingulum. Note the valvocopula with small pores and the smooth cingular bands, cultured material, TEM. (20) Thalassiosira tenera cell in valve view. The arrow points at the rimoportula, natural sample, SEM. (21) $T$. tenera cell in valve view, natural sample, TEM. (22) T. tenera central fultoportula, natural sample, TEM. Scale bars $=10 \mu \mathrm{m}$ (Figure 20); $5 \mu \mathrm{m}$ (Figures 14, 21); $1 \mu \mathrm{m}$ (Figures 12, 13, 17-19, 22); $0.1 \mu \mathrm{m}$ (Figures 15, 16).

Taxonomic description Cells are small, with a conical epitheca and rounded, slightly asymmetrical hypotheca (Figures 23,24$)$ as wide as the epitheca. The cingulum is displaced less than one times its width. The sulcus has five plates. A small left posterior sulcal plate (lps) and a conspicuous left anterior sulcal plate (las) are evident in the central part of the sulcal area (Figure 23). The posterior sulcal plate is rather large and pentagonal. The theca is covered with organic, triangular body scales (not observed in our specimens), which are a remnant of the endosymbiontic prasinophyte from which the chloroplasts of this species derive (Hansen 1995).
Notes The species was identified by shape and size of the cell and the shape of most thecal plates, which perfectly match the holotype of Heterocapsa minima showed by Pomroy (1989). However, in that paper the first cingular plate 1c was interpreted as las, whereas only one relatively large platelet, identified as lps, was described in the central part of the sulcus. Our specimen (Figure 23) clearly has two plates, namely, the actual las and a small lps, in the same position as the lps of Pomroy (1989), who probably missed the suture between these two small plates. This interpretation of the sulcus has already been suggested in a study describ- 


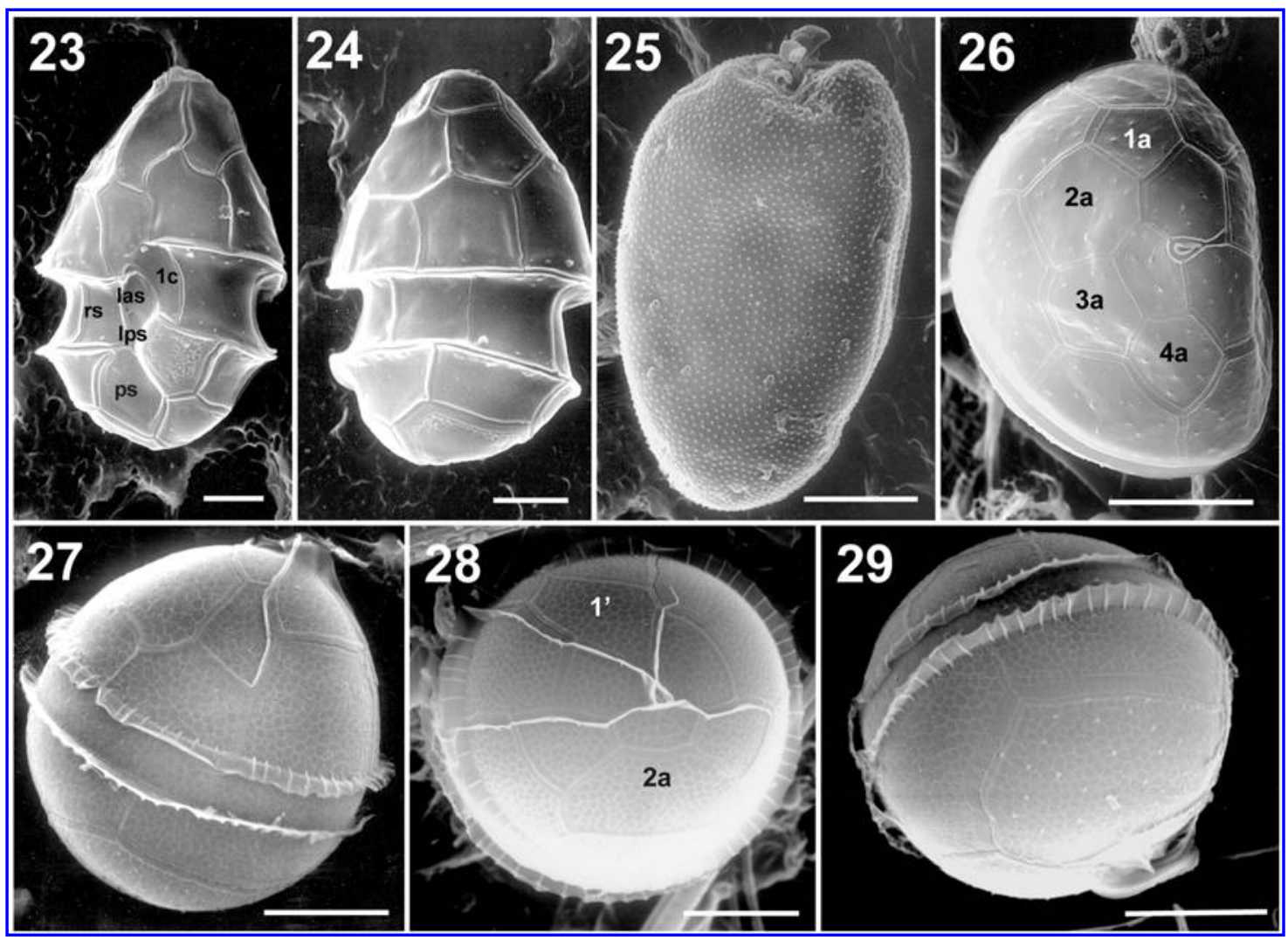

Figures 23-29 Dinophyceae of the Liguro-Provençal basin in the northwestern Mediterranean Sea.

(23) Heterocapsa minima cell in ventral view. Note the five sulcal plates (las, left anterior sulcal; lps, left posterior sulcal; rs, right sulcal; ps, posterior sulcal) and the first cingular plate (1c), net sample, SEM. (24) H. minima cell in dorsal view, net sample, SEM. (25) Prorocentrum donghaiense right valve, net sample, SEM. (26) Protoperidinium americanum cell in apical view. Note the four intercalary plates (1a, 2a, 3a, 4a). (27) Protoperidinium cf. brachypus cell in right-lateral view, net sample, SEM. (28) P. cf. brachypus cell in apical view, net sample, SEM. (29) $P$. cf brachypus cell in right-posterior view, the sulcal wing probably covering the left antapical spine, net sample, SEM. Scale bars $=10 \mu \mathrm{m}$ (Figures 26-29); $5 \mu \mathrm{m}$ (Figure 25); $1 \mu \mathrm{m}$ (Figures 23, 24).

ing another small species in this genus, H. rotundata Hansen (Hansen 1995). Had this suture been observed, the sulcal plate arrangement of $H$. minima would match that of our specimen. Compared to $H$. minima, $H$. rotundata has the same sulcal plate arrangement but the sulcal posterior plate is smaller, the hypotheca is shorter and narrower, and the theca is considerably thinner and smoother. In addition, the body scales of the two species may be slightly different (Hansen 1995).

Distribution This is the first record of Heterocapsa minima in the Mediterranean Sea. The species is also commonly found in the Gulf of Naples in the Tyrrhenian Sea (D. Sarno and A. Zingone, unpublished data). The species was described from the Celtic Sea (Pomroy 1989) and later reported from the North Sea (Hansen and Larsen 1992, Kuylenstierna and Karlson 2000, Hoppenrath 2004).

\section{Prorocentrum donghaiense Lu 2001 (Figure 25)}

Reference Lu and Goebel 2001, p. 338, fig. 2.

Morphometric data Length: $16.5 \mu \mathrm{m}$; width: $9.5 \mu \mathrm{m}$.
Taxonomic description Cells are asymmetrical, with a rounded posterior end and a slightly indented anterior margin. The periflagellar area on the right valve is V-shaped. Knob-like spines cover the whole cell surface. Several circular thecal pores are scattered on the cell surface, sometimes arranged in rows of three or four (Figure 25). Less numerous trichocyst pores are distributed mainly close to the margins of the hypothecal plates.

Notes Our specimen perfectly matches the original description of Prorocentrum donghaiense (Lu and Goebel 2001). Similar specimens isolated from the Gulf of Naples were genetically identical to $P$. donghaiense (R. Siano, unpublished data). Moreover, this species resembles $P$. maximum (Gourret) Schiller, originally described from the Gulf of Marseille as Postprorocentrum maximum Gourret. In the original diagnosis showing an incomplete line drawing, there is no indication of cell size. Schiller (1933) transferred the species to Prorocentrum maximum Schiller, mistakenly omitting the name of Gourret from the authority, and he provided two new line drawings of specimens from the Adriatic Sea. One drawing shows pores of different size scattered on the whole theca, which are also mentioned in the diagnosis (Schiller 
1933). This first occurrence of $P$. donghaiense in the Mediterranean Sea, not far from the type locality of $P$. maximum, raises some doubts whether the two species are distinct. Indeed, $P$. donghaiense is very similar to $P$. maximum in the shape of the theca and dimensions. Different from the original illustration of P. maximum (Schiller 1933), P. donghaiense has large trichocyst pores mainly distributed close to the valve margins, whereas small pores are scattered on the whole surface but are barely visible in LM. Indeed no SEM micrographs of $P$. maximum have ever been provided; such images may have revealed the pore patterns on the cell surface. Unfortunately, in describing $P$. donghaiense, Lu and Goebel (2001) did not discuss the close resemblance with $P$. maximum, likely because the latter species had been synonymized with $P$. mexicanum Tafall (Dodge 1975, Faust et al. 1999). This synonymy was subsequently invalidated by Gómez (2005). Given the poor quality of illustrations in the old literature and the taxonomic and nomenclatural uncertainty regarding P. maximum, we believe that all similar specimens in the Mediterranean Sea will be identified hereafter as $P$. donghaiense, leaving the enigma of the relationships between $P$. maximum and $P$. donghaiense unresolved.

Distribution The species was recorded in East (Qi and Yang 2003, Lu et al. 2005) and South China seas and in Hong Kong (Hodgkiss and Yang 2001). It was reported by Horiguchi (1990) as Prorocentrum dentatum Stein from Korean and Japanese coastal waters. This is the first report of this species in the Mediterranean Sea; it is also relatively common in the Gulf of Naples (D. Sarno and A. Zingone, unpublished data).

\section{Protoperidinium americanum (Gran et Braarud) Balech 1974 (Figure 26)}

Basionym Peridinium americanum Gran and Braarud 1935, p. 377, fig. 54.

References Lewis and Dodge 1987, p. 119, figs. 1-7; Bérard-Therriault et al. 1999, p. 177, pl. 97a-c, f.

\section{Morphometric data Cell width: $35 \mu \mathrm{m}$.}

Taxonomic description The species is characterized by the presence of four intercalary plates on the epitheca, which is quite unusual since congeneric species only have two or three intercalary plates. The apical pore is attached to the first apical plate by a canal plate. Trichocysts are scattered on the thecal plates (Figure 26). Only an anterior view of one specimen was observed in SEM.

Distribution Protoperidium americanum has been reported from the west coasts of Ireland (Gran and Braarud 1935), Britain (Parke and Dixon 1976) and Scotland (Lewis and Dodge 1987), from northwestern Spain (Gaarder 1954), the Gulf of St. Lawrence, Eastern Canada (Bérard-Therriault et al. 1999), Gulf of Maine and South Atlantic waters (Borgese 1987). This is the first occurrence of this species in the
Mediterranean Sea, which has been previously reported only as resting cysts in the Gulf of Naples (Montresor et al. 1998).

\section{Protoperidinium cf. brachypus Abé 1981 (Figures 27-29)}

Reference Abé 1981, p. 224, fig. 20, not Protoperidinium brachypus Schiller 1937.

Morphometric data Length: $36 \mu \mathrm{m}$; width: $30 \mu \mathrm{m}$.

Taxonomic description Cells are ovoid in ventral view and almost circular in cross section, with an equatorial girdle. Both epithecal and hypothecal margins are rounded (Figure 27). The cingulum has a well-developed wing with radial ribs. A small apical horn (Figure 27) and two antapical spines are present (Figure 29). The 1' (first apical) plate has six sides (para) and the $2 \mathrm{a}$ (second intercalary) is a large hexagonal plate (hexa) (Figure 28). Four longitudinal sutures with narrow lists are visible, of which the right anterior does not reach the cingulum (Figure 28). The ornamentation of the theca is a fine reticulation.

Notes Our specimens match the plate pattern and shape of single plates originally described for Protoperidiuim brachypus by Abé (1981). The narrow longitudinal lists on the epitheca are also very similar to those illustrated by Abé (1981). However, P. brachypus is larger (55-63 $\mu \mathrm{m}$ long and $46-55 \mu \mathrm{m}$ wide) and its overall body shape is described and drawn as bi-conical, rather than spherical. Our specimens also show some similarities with $P$. capurroi Balech, a species with rounded cells described from the southwestern Atlantic (Balech 1971), and P. capurroi var. pellucidum (Balech) Balech, which matches our specimens in cell size. Later, Balech (1994) suggested that $P$. brachypus and $P$. capurroi could possibly belong to the same species, but without making any formal statement on this matter. Therefore, this taxonomic uncertainty and the lack of original illustrations other than line drawings prevent us from correctly assigning our specimens to either of the two above species, i.e., P. brachypus or P. capurroi. A ventral view of our specimens is missing, but would not have solved the identification problem.

Distribution There is no information on the distribution of Protoperidinium brachypus and P. capurroi (Gómez 2005), outside their type locality occurrence in Shimoda, Japan (Abé 1981) and southwestern Atlantic (Balech 1971), respectively.

\section{Coccolithophyceae}

\section{Anthosphaera sp. type B sensu Cros and Fortuño 2002 (Figure 30)}

Reference Cros and Fortuño 2002, p. 60, fig. 88b.

Morphometric data Coccosphere diameter: $2.9 \mu \mathrm{m}$; body coccolith diameter: $0.6 \mu \mathrm{m}$; circum-flagellar coccolith height: ca. $1.3 \mu \mathrm{m}$. 
Taxonomic description Monothecate dimorphic coccosphere. The cell body is oval. The body coccoliths have a thin rim constituted of a ring, one-crystal wide, and a central dome formed by few crystals. The circum-flagellar coccoliths have flat leaf-like process (fragarioliths) with straight sides (Figure 30).

Notes Anthosphaera sp. type B can be distinguished from A. fragaria Kamptner by the body and circum-flagellar coccolith morphology and size. Both types of coccoliths of A. fragaria are bigger, and body coccoliths have a more prominent dome-shaped central part and a proximal rim comprising three rows of crystals. Our Anthosphaera sp. type B specimens are smaller than those reported by Cros and Fortuño (2002).

Distribution This species has only been reported from the northwestern Mediterranean Sea (Cros and Fortuño 2002).

\section{Gephyrocapsa muellerae Bréhéret 1978 (Figure 31)}

References Bréhéret 1978, p. 448, pl. 2, figs. 3-4; Samtleben 1980 , p. 106, pl. 14, figs. 6-8, pl. 15, figs. 1-4; Kleijne 1993, p. 230, pl. 2, fig. 4; Cros and Fortuño 2002, p. 46, fig. 61a; Young et al. 2003, p. 10, pl. 2, figs. 6-9; Malinverno et al. 2008, p. 44, fig. 16.

Morphometric data Coccosphere diameter: 4.7-8.2 $\mu \mathrm{m}$; body coccoliths (placoliths) length: 3.5-3.7 $\mu \mathrm{m}$.

Taxonomic description Monothecate monomorphic coccosphere. The cell body is spherical. The body coccoliths (placoliths) have a narrow central area and a bar forming an angle of $45^{\circ}$ to the long axis of the coccolith (Figure 31). The larger placoliths and the larger angle of the bar distinguish Gephyrocapsa muellerae from the congeneric species G. ericsonii McIntyre et Bé.

Distribution This species has a cosmopolitan distribution. In the Mediterranean Sea, it has been recorded in both eastern (Kimor and Wood 1975, Malinverno et al. 2008) and western basins (Cros and Fortuño 2002).

\section{Poritectolithus poritectus (Heimdal) Kleijne 1991 (Figures 32, 33)}

Basionym Helladosphaera poritectum Heimdal in Heimdal et Gaarder 1980, p. 7, pl. 2, fig. 15a-b.

References Cros and Fortuño 2002, p. 66, fig. 102a-b; Young et al. 2003, p. 102, figs. 1-3.

Morphometric data Coccosphere diameter: $8.5 \mu \mathrm{m}$; body coccolith length: $1.8 \mu \mathrm{m}$; body coccolith width: $1.3 \mu \mathrm{m}$; body coccolith height: $0.4 \mu \mathrm{m}$; circum-flagellar coccolith length: $1.9 \mu \mathrm{m}$.

Taxonomic description Monothecate dimorphic coccosphere. The cell body is irregular in shape. The dome- shaped body coccoliths are formed by large crystalliths with an evident rim. The circum-flagellar coccoliths (helladoliths) have a flared wall and a large protrusion (Figures 32, 33).

Distribution The species has been reported from the northwestern (Cros and Fortuño 2002) and eastern basins of the Mediterranean Sea as Poritectolithus cf. poritectus. It has also been recorded in the Caribbean Sea (Winter et al. 2002) and Indian Ocean (Takahashi 1981).

\section{Syracosphaera corolla Lecal 1965 (Figures 34, 35)}

Synonyms Gaarderia corolla (Lecal) Kleijne 1993, p. 252, pl. 1, figs. 1-4; Syracolithus corolla Lecal 1965, p. 252, pl. 1, fig. 2; Umbellosphaera corolla (Lecal) Gaarder in Heimdal and Gaarder 1981, p. 62, 64, pl. 11, figs. 52-57.

References Cros and Fortuño 2002, p. 29, fig. 29; Young et al. 2003, p. 44, figs. 13-15; Malinverno et al. 2008, p. 105 , fig. 76 .

Morphometric data Body coccoliths: $2.2 \mu \mathrm{m}$; exothecal coccolith length: $4.4 \mu \mathrm{m}$.

Taxonomic description Dithecate monomorphic coccosphere. Cell body is oval. Body coccoliths have a beaded mid-wall flange and a chiral distal flange (Figure 34). Exothecal coccoliths have a petaloid-shaped distal flange showing chirality, with an evident anticlockwise direction (Figure 35).

Distribution This species has been recorded in both western (Cros and Fortuño 2002) and eastern basins (Malinverno et al. 2008) of the Mediterranean Sea. It has also been reported from both Atlantic and Pacific oceans (Heimdal 1993).

\section{Syracosphaera didyma Kleijne et Cros 2009 (Figure 36)}

Synonyms Syracosphaera exigua auct. non Okada et McIntyre 1977, p. 21, pl. 8, figs. 10-11; Syracosphaera sp. type D sensu Kleijne 1993, p. 242, pl. 6, figs. 7-8.

References Young et al. 2003, p. 44, figs. 9, 12; Cros and Fortuño 2002, p. 41, fig. 53a-d; Malinverno et al. 2008, p. 104, fig. 75; Kleijne and Cros 2009, p. 430, pl. 3, figs. $1-6$.

Morphometric data Coccosphere long axis: $9.3 \mu \mathrm{m}$; body coccoliths length: $3.1 \mu \mathrm{m}$; circum-flagellar coccoliths spine length: $2.0 \mu \mathrm{m}$.

Taxonomic description Dithecate dimorphic coccosphere. The cell body is spherical. The body coccoliths have beaded mid-wall flange and a distal flange with nodules on its inner part. The circum-flagellar coccoliths have beaded mid-wall flange and a robust spine (Figure 36). No exothecal coccoliths were observed. 


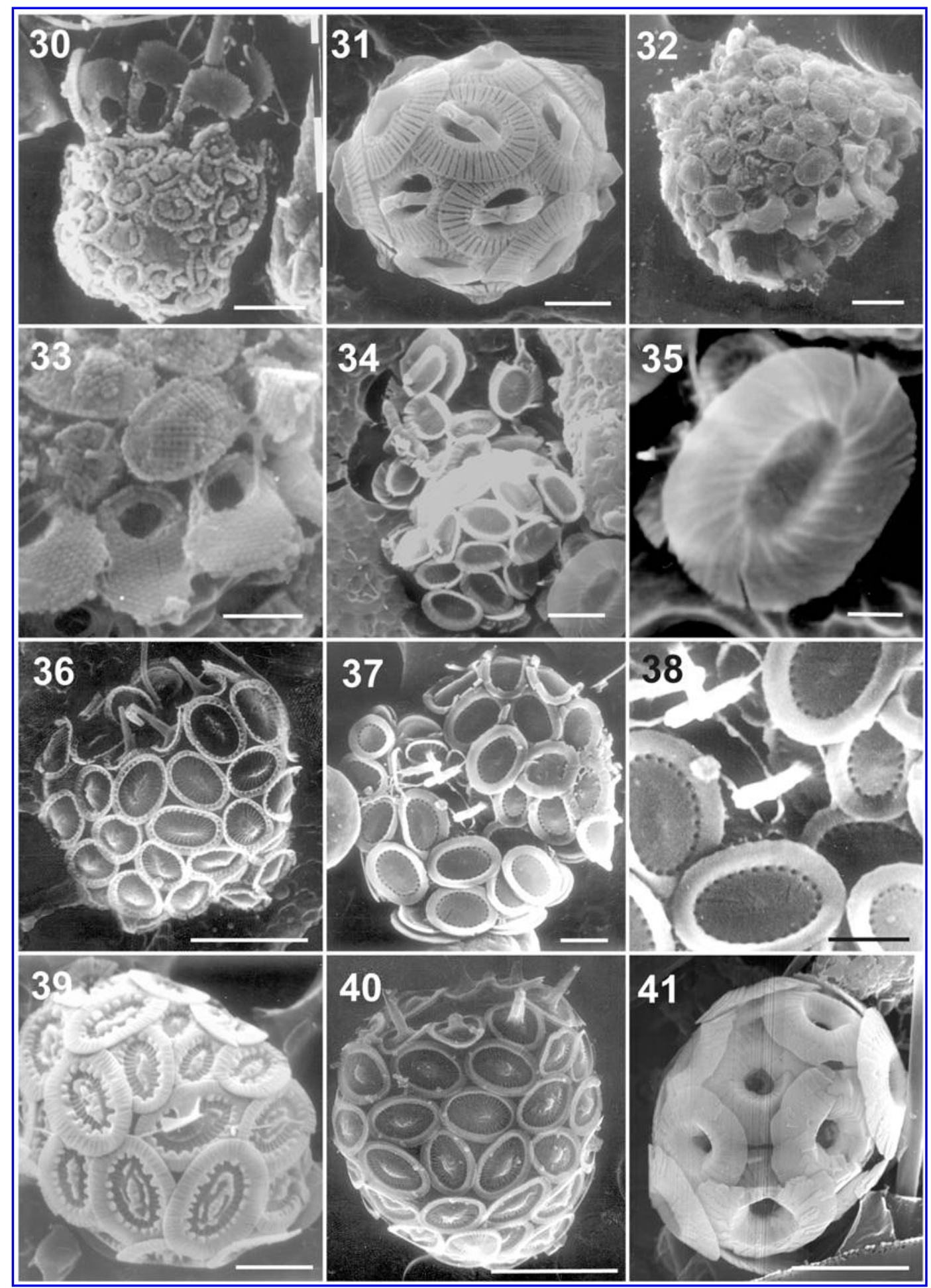

Figures 30-41 Coccolithophyceae of the Liguro-Provençal basin in the northwestern Mediterranean Sea.

(30) Anthosphaera sp. type B complete coccosphere with fragarioliths, natural sample, SEM. (31) Gephyrocapsa muellerae complete coccosphere, natural sample, SEM. (32) Poritectolitus poritectus complete coccosphere, net sample, SEM. (33) P. poritectus detail of circumflagellar coccoliths, net sample, SEM. (34) Syracosphaera corolla coccosphere showing endothecal and exothecal coccoliths, natural sample, SEM. (35) S. corolla detail of an exothecal coccolith, natural sample, SEM. (36) Syracosphaera didyma coccosphere showing endothecal and circum-flagellar coccoliths, natural sample, SEM. (37) Syracosphaera marginaporata collapsed coccosphere, natural sample, SEM. (38) S. marginaporata detail of the circum-flagellar area, natural sample, SEM. (39) Syracosphaera molischii coccosphere showing endothecal coccoliths, natural sample, SEM. (40) Syracosphaera prolongata coccosphere showing endothecal and circum-flagellar coccoliths, natural sample, SEM. (41) Umbilicosphaera foliosa complete coccosphere, net sample, SEM. Scale bars $=5 \mu \mathrm{m}$ (Figures 36,40 , 41); $2 \mu \mathrm{m}$ (Figures 31, 32, 34, 39); $1 \mu \mathrm{m}$ (Figures 30, 33, 37, 38); $0.5 \mu \mathrm{m}$ (Figure 35). 
Notes The association of Syracosphaera didyma with Homozygosphaera arethusae (Kamptner) Kleijne is still uncertain, as Cros et al. (2000) only reported two ambiguous combination coccospheres.

Distribution The species has been recorded in the northwestern (Cros and Fortuño 2002) and eastern Mediterranean Sea (Malinverno et al. 2008).

\section{Syracosphaera marginaporata Knappertsbusch 1993 (Figures 37, 38)}

Synonyms Syracosphaera sp. A sensu Samtleben and Schröder 1990, pl. 1, fig. 3; Syracosphaera type H sensu Kleijne 1993, p. 5, fig. 6.

References Knappertsbusch 1993, p. 72, pl. 2, figs. 1-4; Cros and Fortuño 2002, p. 30, fig. 30a-d; Young et al. 2003, p. 46, figs. 13-15; Malinverno et al. 2008, p. 98, fig. 68.

Morphometric data Coccosphere diameter: 4.3$6.9 \mu \mathrm{m}$; body coccolith length: $1.8 \mu \mathrm{m}$; body coccolith width: $1.4 \mu \mathrm{m}$; circum-flagellar coccolith length: $1.1 \mu \mathrm{m}$; circum-flagellar coccolith width: $0.68 \mu \mathrm{m}$.

Taxonomic description Dithecate dimorphic coccosphere. The cell body is spherical. The body coccoliths are flat with a smooth distal flange (Figure 37). The circumflagellar coccoliths are smaller than the body ones and bear a spine (Figure 38). The central area is smooth with a ring of pores on the margin. No exothecal coccoliths were observed.

Distribution The species has been reported from both the western (Cros and Fortuño 2002) and eastern basins (Malinverno et al. 2008) of the Mediterranean Sea. It has also been recorded in the Norwegian-Greenland Sea (Samtleben et al. 1995) and in the North Atlantic Ocean (Knappertsbusch 1993).

\section{Syracosphaera molischii Schiller 1925 (Figure 39)}

Synonyms Caneosphaera molischii (Schiller) Gaarder in Gaarder and Heimdal 1977, p. 66, pl. 7, figs. 40-46, pl. 8, figs. 47-49; Syracosphaera corrugis Okada et McIntyre 1977, p. 24, pl. 8, figs. 4-5; Syracosphaera elatensis Winter in Winter et al. 1979, p. 207, pl. 3, figs. 11-13.

References Schiller 1925, p. 21, fig. K; Cros and Fortuño 2002, p. 30, fig. 31a-d; Young et al. 2003, p. 46, figs. 4,7 .

Morphometric data Coccosphere major axis: $7.7 \mu \mathrm{m}$; coccosphere minor axis: $6.0 \mu \mathrm{m}$; body coccolith length: $2.9 \mu \mathrm{m}$; body coccolith width: $2.1 \mu \mathrm{m}$.

Taxonomic description Dithecate dimorphic coccosphere. Cell body is ovoid. The body coccoliths have a broad distal flange. The outer part of distal flange has low radial ridges and the inner part has teeth-like projections. A slightly developed ridge is located centrally, parallel to the long axis of the plate (Figure 39). The circum-flagellar coccoliths (caneoliths) are smaller than the body ones and bear a conspicuous central spine. No exothecal coccoliths were observed. Our specimen corresponds to S. molischii type 2 (see Young et al. 2003, Malinverno et al. 2008).

Notes Cros et al. (2000) illustrated a single collapsed coccosphere from the northwestern Mediterranean Sea, showing dimorphic endothecal coccoliths of Syracosphaera molischii in combination with both ordinary and circum-flagellar coccoliths of Anthosphaera fragaria.

Distribution This species has been recorded in the northwestern Mediterranean Sea (Cros and Fortuño 2002). It has also been reported in the Norwegian Sea, Atlantic, Indian and Pacific oceans and in Australian waters (Heimdal 1993).

\section{Syracosphaera prolongata Gran ex Lohmann type 2 sensu Heimdal and Gaarder 1981 (Figure 40)}

References Heimdal and Gaarder 1981, p. 62, pl. 10, figs. 48-50; Young et al. 2003, p. 42, figs. 12, 15.

Morphometric data Coccosphere long axis: $10 \mu \mathrm{m}$; body coccolith width: $2.4-2.8 \mu \mathrm{m}$.

Taxonomic description Dithecate dimorphic coccosphere. The cell body is ovoid to elongate. The body coccoliths have three smooth flanges and the central area has laths converging in the center and forming a twisted mound (Figure 40). The circum-flagellar coccoliths have a central spine. No exothecal coccoliths were observed.

Distribution The species is present in the northwestern Mediterranean Sea (Cros and Fortuño 2002), along Egyptian (Kimor and Wood 1975) and Tunisian coasts (Saugestad and Heimdal 2002) and the Gulf of Naples (D. Sarno and A. Zingone, unpublished data). The species has also been reported from the Atlantic Ocean (Heimdal 1993).

\section{Umbilicosphaera foliosa (Kampter ex Kleijne) Geisen 2003 (Figure 41)}

Basionym Cycloplacolithus foliosus Kamptner 1963, p. 167 , pl. 7, fig. 38 .

Synonyms Cyclococcolithus mirabilis (Lohmann) Kamptner 1954, p. 24, figs. 21-23; Umbilicosphaera mirabilis Lohmann 1902, p. 139, pl. 17, figs. 1-2; Umbilicosphaera sibogae var. foliosa (Kamptner) Okada et McIntyre 1977, p. 13, pl. 4, fig. 1.

References Cros and Fortuño 2002, p. 49, fig. 64a-b; Young et al. 2003, p. 20, figs. 10-12; Malinverno et al. 2008, p. 35 , fig. 7 . 


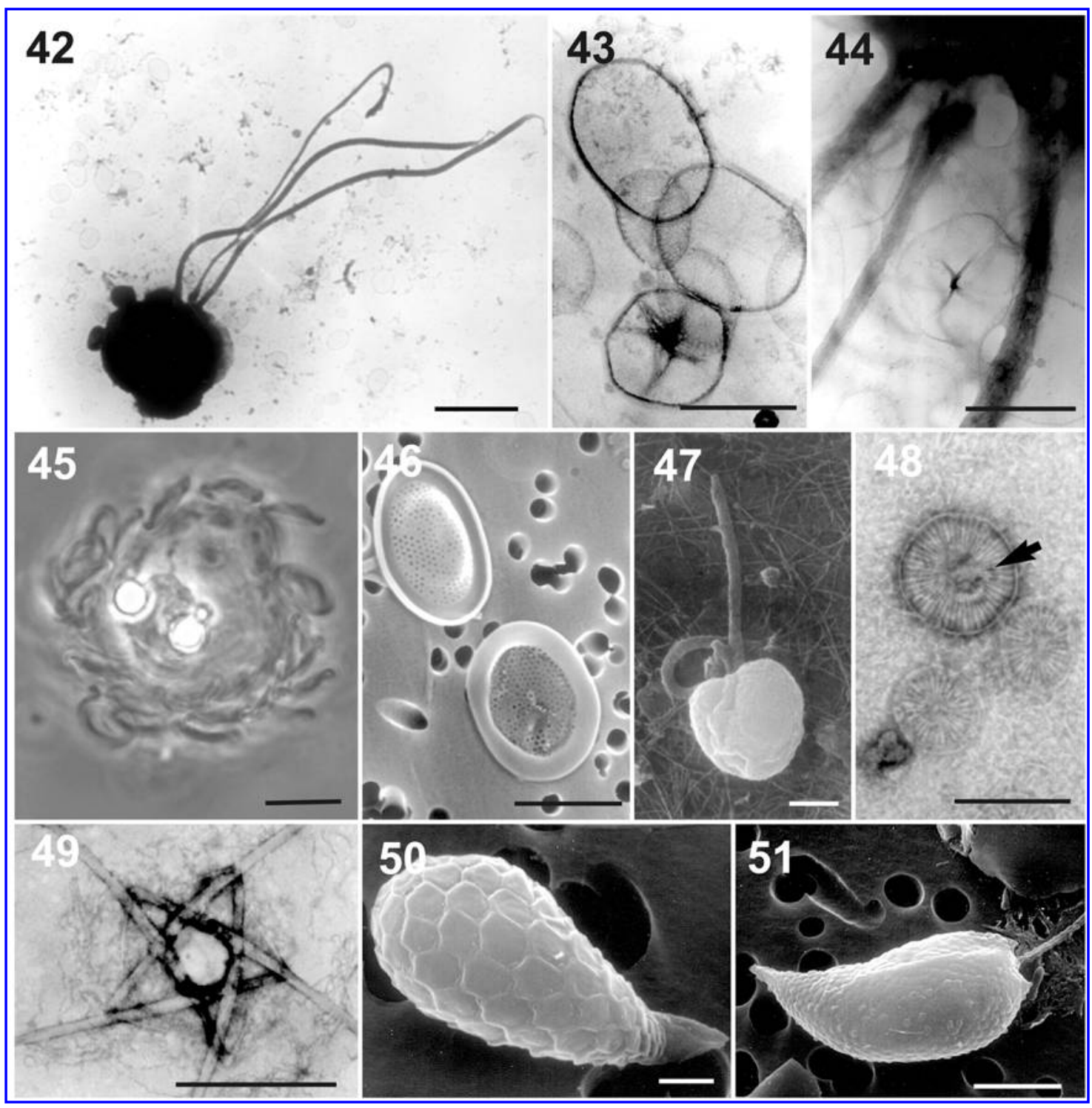

Figures 42-51 Prymnesiophyceae and Cryptophyceae of the Liguro-Provençal basin in the northwestern Mediterranean Sea.

(42) Chrysochromulina kappa cell with two flagella and a haptonema, cultured material, TEM. (43) C. kappa three types of scales, cultured material, TEM. (44) C. kappa spine scale at the haptonema base, cultured material, TEM. (45) Hyalolithus neolepis cell with typical hat-shaped siliceous scales, net sample, LM. (46) H. neolepis proximal and distal view of two scales, net sample, SEM. (47) Phaeocystis sp. cell with two flagella and the short haptonema, natural sample, SEM. (48) Phaeocystis sp. different scales. Note the subcircular structure in the larger scale (arrow), cultured material, TEM. (49) Phaeocystis sp. three detail of the five-filament structure, cultured material, TEM. (50) Plagioselmis prolonga cell in dorsal view, natural sample, SEM. (51) Teleaulax acuta cell with the typical pointed posterior end, natural sample, SEM. Scale bars=10 $\mu \mathrm{m}$ (Figure 45); $5 \mu \mathrm{m}$ (Figures 46, 51); $1 \mu \mathrm{m}$ (Figures 42, 47, 50); $0.5 \mu \mathrm{m}$ (Figures 43, 44, 49); $0.2 \mu \mathrm{m}$ (Figure 48).

Morphometric data Coccosphere diameter: $12 \mu \mathrm{m}$; body coccolith diameter: $5.5 \mu \mathrm{m}$.

Taxonomic description Monothecate monomorphic coccosphere. The cell body is spherical. The body coccoliths (placoliths) have small opening and distal shield larger than the proximal shield (Figure 41). One or more hook-like spines are often visible in the central area.

Distribution The species has been recorded from the eastern (Malinverno et al. 2008) and western basins (Cros and Fortuño 2002) of the Mediterranean Sea, including the Gulf of Salerno (A. Zingone, unpublished data). It has been recorded in Atlantic, Pacific and Australian waters (Heimdal 1993).

\section{Prymnesiophyceae}

\section{Chrysochromulina kappa Parke et Manton 1955 (Figures 42-44)}

Reference Parke et al. 1955, p. 583, pl. 1-4. 
Morphometric data Cell diameter: 3.2-4.0 $\mu \mathrm{m}$; haptonema length: $9.7 \mu \mathrm{m}$; flagellum length: 10.0-12.6 $\mu \mathrm{m}$; large plate scales: $0.6-0.7 \times 0.4-0.5 \mu \mathrm{m}$; small plate scales: $0.2-0.3 \times 0.3-0.4 \mu \mathrm{m}$; spine scales: $0.5-0.6 \mu \mathrm{m}$.

Taxonomic description Cells are spherical to subspherical in shape, with two chloroplasts. When fully extended, the haptonema has approximately the same length as the flagella (Figure 42). Cells are covered with three types of scales of different size and ornamentation: large plate scales with a raised rim, small plate scales and very few spine scales located near the haptonemal base (Figures 43, 44). Both types of plate scales have a crossing pattern of microfibrils.

Distribution The species has been reported from British (Parke et al. 1955) and Norwegian waters as Chrysochromulina cf. kappa in Throndsen (1969). This is the first occurrence of this species in the Mediterranean Sea, except for a previous report from Greece (Nikolaidis and Moustaka-Gouni 1990) that lacks confirmation in EM (see below).

Notes In LM, Chrysochromulina kappa can be confused with the related species $C$. minor Parke et Manton, C. brachycylindra Hällfors et Thomsen, C. leadbeaterii Estep, Davis, Hargraves et Sieburth, sharing similar cell diameter and length of the flagella and haptonema. The species identification can only be confirmed in EM by the examination of the scale shape and size.

\section{Hyalolithus neolepis Yoshida, Noël, Nakayama, Naganuma et Inouye 2006 (Figures 45, 46)}

Reference Yoshida et al. 2006, p. 214, figs. 1-2.

Morphometric data Cell diameter with scales: $30 \mu \mathrm{m}$; scale length: $7.6 \mu \mathrm{m}$; scale width: $5.0 \mu \mathrm{m}$.

Taxonomic description Cells are spherical to subspherical in shape and have two yellowish and rounded chloroplasts (Figure 45). Cells are covered with typical hat-shaped siliceous scales (Figure 46). The central area of these scales is perforated by small pores and cup-shaped, with a concavity at its top produced by the presence of two bulges (Figure 46). The marginal rim of the scale is smooth and bent upwards.

Distribution The siliceous scales of this species are found worldwide, including in the Adriatic Sea (Yoshida et al. 2006). Whole cells have been recorded only in Japanese waters (Yoshida et al. 2006) from which they have been cultured. This is the first occurrence of whole cells in the Mediterranean Sea, where they are also found in the Gulf of Naples (A. Zingone, unpublished data).

\section{Phaeocystis sp. 3 sensu Medlin and Zingone 2007 (Figures 47-49)}

Reference Medlin and Zingone 2007, p. 12, fig. 6g.
Morphometric data Cell diameter: $3.5 \mu \mathrm{m}$; larger circular scales: $0.19-0.22 \mu \mathrm{m}$; smaller oval scales: $0.16-0.18 \times 0.14-0.15 \mu \mathrm{m}$.

Taxonomic description Cells show the typical heartlike shape with the two flagella and the haptonema emerging from a depression in the cell body (Figure 47). The flagella are subequal in length. Cells are covered by two layers of different body scales: the external layer has larger, circular plates and the internal one has smaller, oval plates (Figure 48). In the larger scales, a subcircular structure is at times visible in the middle of the scale surface (Figure 48, arrow). The five-filament structure ejected by the cells has a fivepointed star in its center, often surrounded by dense material, possibly of mucous nature, with a circular hole in the center of the star-like structure (Figure 49).

Distribution The species (strains MEDNS2 and MEDSN3) was recorded for the first time in the northwestern Mediterranean Sea and initially attributed to Phaeocystis cordata Zingone et Chrétiennot-Dinet (Zingone et al. 1999). However, the scales of $P$. cordata are oval $(0.25 \times 0.18 \mu \mathrm{m})$. In addition, molecular analysis places Phaeocystis sp. 3 within the $P$. globosa-complex rather than with P. cordata (Medlin and Zingone 2007).

\section{Cryptophyceae}

\section{Plagioselmis prolonga Butcher ex Novarino, Lucas et Morrall 1994 (Figure 50)}

References Butcher 1967, p. 18, pl. 1, fig. 9, pl. 14, fig. 2; Hill 1992a, p. 165, figs. 1A-P; Novarino et al. 1994, p. 90, figs. 1-18; Novarino 2005, p. 62, fig. 8; Cerino and Zingone 2006, p. 367, figs. 9-13.

Morphometric data Length: $6.0-13.0 \mu \mathrm{m}$; width: 3.0-5.9 $\mu \mathrm{m}$.

Taxonomic description Cells have a tear-drop shape with a round anterior end and a prominent tail at the posterior end (Figure 50). Cells bear two slightly subequal flagella, the right one shorter than the left one. A furrow runs posteriorly from the vestibulum along the ventral surface and extends for about one-third of the cell length. The inner periplast component has hexagonal plates, which are absent in the vestibular area and on the tail.

Distribution Largely distributed worldwide, Plagioselmis prolonga has been recorded in British waters (Butcher 1967), Irish and Baltic seas (Hill 1992a), Skagerrak, North Sea (Kuylenstierna and Karlson 1994), La Rochelle, France (Pastoureaud et al. 2003, Charles et al. 2005, Novarino 2005), and San Francisco Bay (Cloern and Dufford 2005) and Salton Sea in California (Barlow and Kugrens 2002). In the Mediterranean Sea, the species has been recorded along Spanish coasts and the Alboran Sea (Margalef 1969, Novarino 2005), Gulf of Naples (Cerino and Zingone 2006), and Adriatic Sea near the Po River delta lagoon (Andreoli et al. 1986). 


\section{Teleaulax acuta (Butcher) Hill 1991 (Figure 51)}

Basionym Cryptomonas acuta Butcher 1952, pl. 2, figs. 51-53.

References Butcher 1967, pl. 5, fig. 4, pl. 18, fig. 6; Hill 1991, p. 178, figs. 16-24; Hill 1992b, p. 173, fig. 1a-m; Bérard-Therriault et al. 1999, p. 250, pl. 116e; Cerino and Zingone 2006, p. 373, figs. 45-46.

\section{Morphometric data Length: $8.1 \mu \mathrm{m}$; width: $3.8 \mu \mathrm{m}$.}

Taxonomic description Cells have a strongly rostrate anterior and a pointed posterior end. Flagella are sub-equal in length. Cells have a long, deep furrow extending for about half the cell length (Figure 51). The periplast has an inner sheet, without discrete plates (Figure 51).

Distribution In the Mediterranean Sea, the species has been recorded in the Gulf of Naples (Cerino and Zingone 2006) and in Alboran Sea and Barcelona coastal waters (Novarino 2005). It has been also reported from British coastal waters (Butcher 1952, 1967), Baltic Sea (Hill 1992b), North Sea (Novarino et al. 1997), Gulf of St. Lawrence in eastern Canada (Bérard-Therriault et al. 1999), Salton Sea in California (Barlow and Kugrens 2002), and Victoria in Australia (Hill 1991).

\section{Discussion}

The eukaryotic phytoplankton assemblage in the Liguro-Provençal basin of the Mediterranean Sea is relatively speciose in the spring season, with a total number of 168 taxa recorded during the 2-year study. This is certainly a conservative estimate, considering that, originally, this study was not strictly focused on species diversity and hence the identification of some groups of species, e.g., the unarmored dinoflagellates, was not properly addressed. Our species list is dominated by diatoms, which cover almost half of the total diversity recorded in the area. Most of these diatoms (e.g., Chaetoceros spp., Thalassiosira spp., Pseudo-nitzschia spp.) are a common component of the spring phytoplankton bloom occurring in other areas of the Mediterranean Sea (SiokouFrangou et al. 2010), while others are very rare. Velasquez and Cruzado (1995) revised the diatom flora of the northwestern Mediterranean Sea based on literature since 1883 and their own material. They came up with a list of 753 taxa, including 504 pennates and 249 centrics. In this study, the low number of diatom species recorded with 54 centrics and 19 pennates can be explained by the sampling strategy which was limited both in space and time and did not include coastal, benthic and ticoplanktonic species. Nonetheless, 17 taxa from our species list were not reported in the review of Velasquez and Cruzado (1995) (Table 3). However, among these 17 taxa, a few (e.g., Cyclotella choctawhatcheeana, Dactyliosolen phuketensis, Pseudo-nitzschia galaxiae) had not even been described in 1995, obviously preventing them from appearing in previous reports. Identification inaccura- cies may have also contributed to the lack of records for some species. For example, Thalassiosira cf. allenii may have been misidentified as T. nordenskioeldii Cleve (Marino and Modigh 1981), a species that is typical of cold waters of the Northern Hemisphere (Hasle 1978) and has never been documented in the Mediterranean Sea. In other cases, identification can only be accurately verified through electron microscopy, which has not been frequently used in past studies. Here, we reported the presence of a number of tiny diatoms mainly because they grew well in sufficient numbers in our SDCs and could later be observed in TEM. More specifically, four diatom species, Arcocellulus cornucervis, A. mammifer, Papiliocellulus simplex and Thalassiosira profunda, represent new records for the Mediterranean Sea.

We did not record a high number of dinoflagellate species in the Liguro-Provençal basin, although Gómez (2003) recently reported 673 species of dinoflagellates making a rather diversified group in the Mediterranean Sea. However, the diversity of dinoflagellates is better assessed through net sampling, which we used for only a very minor portion of our collections. In addition, dinoflagellates are more abundant and diverse during the summer months. We also observed many athecate unidentified dinoflagellates in the nano-sized fraction of the plankton $(<20 \mu \mathrm{m})$ in our preserved samples, but not in our SDCs, which would have allowed us to use EM for an accurate identification at the species level. In fact, the diversity of small dinoflagellates can be better addressed with a modified SDC technique, using multiwell plates which allow the observation of less abundant species (Siano et al. 2009). Nonetheless, we provide new information with the first occurrence of Heterocapsa minima, Prorocentrum donghaiense, vegetative cells of Protoperidinium americanum and P. brachypus (or P. capurroi) in the Mediterranean Sea.

The use of culture experiments (SDCs) during the NORBAL cruises allowed us to address a usually neglected component of the phytoplankton, i.e., the small, naked and soft flagellates. This protocol only reveals the viability of culturable species, which are known to represent a small fraction of all living microscopic eukaryotes in the sea. Some very important fraction of the flagellates could only be detected and identified in cultured material. Among them, EM-identified Chrysochromulina kappa and Imantonia rotunda are reported for the first time in the Mediterranean Sea. In addition, we identified the pelagophyte Pelagomonas calceolata based on its typical cell shape, single flagellum and the peculiar swimming behavior. Pelagophytes have so far been detected in the Mediterranean Sea only through their characteristic pigment signature (Claustre et al. 1994, Barlow et al. 1997, Brunet et al. 2006, 2007) and DNA sequencing (Dìez et al. 2001, Massana et al. 2004, McDonald et al. 2007). Coccolithophores were numerous in the Liguro-Provençal basin, but all of them have been already reported from the northwestern Mediterranean Sea (Cros and Fortuño 2002).

One of the main results of this study is the discovery of many small species usually overlooked with routine identification protocols, which nonetheless can be highly relevant 
to the pelagic food web. In this survey, 17 species, mainly diatoms and flagellates, belong to the eukaryotic picophytoplankton $(<3 \mu \mathrm{m})$, and some of them were very abundant during the bloom period, such as Minidiscus comicus, which contributed up to $40 \%$ of total cell numbers and $20 \%$ of total biomass during the NORBAL 4 cruise in March (Iennaco 2004). Picoeukaryotes are indeed a rather diverse group, with more than 70 species described to date (Vaulot et al. 2008). Their relevance in terms of biomass and primary productivity has been shown in different marine pelagic ecosystems ( $\mathrm{Li}$ 1994, Marañón et al. 2001, Worden et al. 2004, Buck et al. 2008). Nonetheless, small unicellular eukaryotes have received much less attention than the prokaryotes over the last decades, judging by the absence of a taxonomic overview of marine eukaryotic picoplankton since the work of Thomsen (1986).

The high number of new records in this study clearly indicates that the phytoplankton biodiversity of the Mediterranean Sea is far from being completely known. Thorough taxonomic investigations are warranted in more areas and periods of the year in order to get a more complete appreciation of this diversity. It is a most useful task which can provide a baseline for future comparisons, contributing to the identification of phytoplankton shifts in species composition in relation to climate change or harmful/toxic species invasions. In addition, sound taxonomic information is needed to allow interpretation of the huge amount of molecular data that is rapidly accumulating.

\section{Acknowledgments}

We wish to thank the crew of the Urania and the project and cruise organisers Dr. Lia Santoleri (ISAC-CNR), Dr. Maurizio Ribera d'Alcalà and Dr. Daniele Iudicone (Stazione Zoologica Anton Dohrn). A special thank to Ivano Iennaco who contributed to the identification of phytoplankton species, to Gennaro Iamunno and Franco Iamunno for technical assistance with EM and ISAC-CNR for providing physico-chemical data. This work falls within the scope of the European Network of Excellence on Marine Biodiversity and Ecosystem Functioning in European Seas (MARBEF).

\section{References}

Abé, T.H. 1981. Studies on the family Peridinidae, an unfinished monograph of the armoured Dinoflagellata. Publ. Seto Mar. Biol. Lab. 6: 1-409.

Aké-Castillo, J.A., D.U. Hernández-Becerril and M.E. Meave del Castillo. 1999. Species of the genus Thalassiosira (Bacillariophyceae) from the Gulf of Tehuantepec, Mexico. Bot. Mar. 42: 487-503.

Aké-Castillo, J.A., D.U. Hernández-Becerril, M.E. Meave del Castillo and E. Bravo-Sierra. 2001. Species of Minidiscus (Bacillariophyceae) in the Mexican Pacific Ocean. Cryptogam. Algol. 21: 101-107.

Andersen, P. and J. Throndsen. 2003. Estimating cell numbers. In: (G.M. Hallegraeff, D.M. Anderson and A.D. Cembella, eds) Manual on harmful marine microalgae. UNESCO Publishing, Paris. pp. 99-129.
Anderson, V. and L. Prieur. 2000. One month study in the open NW Mediterranean Sea (DYNAPROC experiment, May 1995): overview of the hydrobiogeochemical structures and effects of wind events. Deep-Sea Res. 47: 397-422.

Andreoli, C., C. Tolomio, N. Rascio and L. Talarico. 1986. Some observations on a cryptophycea responsible for a winter red bloom. G. Bot. Ital. 120: 70-71.

Antoine, D. and A. Morel. 1995. Algal pigment distribution and primary production in the eastern Mediterranean as derived from coastal zone color scanner observations. J. Geophys. Res. 100: 16193-16209.

Azov, Y. 1991. Eastern Mediterranean, a marine desert? Mar. Pollut. Bull. 23: 225-232.

Balech, E. 1971. Microplancton de la campana oceanografica Productividad III. Rev. Mus. Argent. Cienc. Nat. Bernardino Rivadavia, Inst. Nac. Invest. Cienc. Nat. Hidrobiol. 3: 1-202.

Balech, E. 1994. Contribucion a la taxinomia y nomenclatura del genero Protoperidinium (Dinoflagellata). Rev. Mus. Argent. Cienc. Nat. Bernardino Rivadavia, Inst. Nac. Invest. Cienc. Nat. Hidrobiol. 7: 61-80.

Barlow, R.G., R.F.C. Mantoura, D.G. Cummings and T.W. Fileman. 1997. Pigment chemotaxonomic distributions of phytoplankton during summer in the western Mediterranean. Deep-Sea Res. II 44: 833-850.

Barlow, S.B. and P. Kugrens. 2002. Cryptomonads from the Salton Sea, California. Hvdrobiologia 473: 129-137.

Bérard-Therriault, L., M. Poulin and L. Bossé. 1999. Guide d'identification du phytoplancton marin de l'estuaire et du golfe du Saint-Laurent incluant également certains protozoaires. Publ. spéc. can. sci. halieut. aquat. 128: 1-387.

Borgese, M.B. 1987. Two armored dinoflagellates from the southwestern Atlantic Ocean: a new species of Protoperidinium and a first record and redescription for Gonyaulax alaskensis. J. Phycol. 34: 332-337.

Bratbak, G., M. Heldal, S. Norland and T.F. Thingstad. 1990. Viruses as partners in spring bloom microbial trophodynamics. Appl. Environ. Microbiol. 56: 1400-1405.

Bréhéret, J.G. 1978. New existing and Quaternary forms of Gephyrocapsaceae (Coccolithophorides) Family. C.R. Hebd. Séances Acad. Sci. Paris 287: 447-449.

Brunet, C., R. Casotti, V. Vantrepotte, F. Corato and F. Conversano. 2006. Picophytoplankton diversity and photoacclimation in the Strait of Sicily (Mediterranean Sea) in summer. I. Mesoscale variations. Aquat. Microb. Ecol. 44: 127-141.

Brunet, C., R. Casotti, V. Vantrepotte and F. Conversano. 2007. Vertical variability and diel dynamics of picophytoplankton in the Strait of Sicily, Mediterranean Sea, in summer. Mar. Ecol. Prog. Ser. 346: 15-26.

Buck, K.R., F.R. Chavez and A.S. Davis. 2008. Minidiscus trioculatus, a small diatom with a large presence in the upwelling systems of central California. Nova Hedwigia 133: 1-6.

Butcher, R.W. 1952. Contribution to our knowledge of the smaller marine algae. J. Mar. Biol. Ass. UK 21: 175-191.

Butcher, R.W. 1967. An introductory account of the smaller algae of the British coastal waters. Part IV: Cryptophyceae. Fish. Invest. 4: 1-54.

Cerino, F. and A. Zingone. 2006. A survey of cryptomonad diversity and seasonality at a coastal Mediterranean site. Eur. J. Phycol. 41: $363-378$.

Charles F., F. Lantoine, S. Brugel, M.-J. Chrétiennot-Dinet, I. Quiroga and B. Rivière. 2005. Seasonal survey of the phytoplankton biomass, composition and production in a littoral NW Mediterranean site, with special emphasis on the picoplanktonic contribution. Estuar. Coast. Shelf Sci. 65: 199-212. 
Chrétiennot-Dinet, M.-J. and N. Guillocheau. 1987. Etude de diatomées d'écosystèmes marins côtiers. Observations nouvelles en microscopie électronique. Cah. Biol. Mar. 28: 271-279.

Claustre, H., P. Kerherve, J.C. Marty, L. Prieur, C. Videau and J.H. Hecq. 1994. Phytoplankton dynamics associated with a geostrophic front: ecological and biogeochemical implications. $J$. Mar. Res. 52: 711-742.

Cloern, J.E. and R. Dufford. 2005. Phytoplankton community ecology: principles applied in San Francisco Bay. Mar. Ecol. Prog. Ser. 285: 11-28.

Coste, B., J. Gostan and H.J. Minas.1972. Influence des conditions hivernales sur les productions phyto et zooplanctoniques en Méditerranée Nord-Occidentale. I: Structures hydrologiques et distribution de sels nutritifs. Mar. Biol. 18: 320-348.

Cros, L. and J.-M. Fortuño. 2002. Atlas of northwestern Mediterranean coccolithophores. Sci. Mar. 66: 7-182.

Cros, L., A. Kleijne, A. Zeltner, C. Billard and J.R. Young. 2000. New example of holococcolith-heterococcolith combination coccospheres and their implication for coccolithophorid biology. Mar. Micropaleontol. 39: 1-34.

Delgado, M. 1990. Phytoplankton distribution along the Spanish coast of the Alboran Sea. Sci. Mar. 54: 169-178.

Delgado, M. and J.-M. Fortuño. 1991. Atlas de fitoplancton del Mar Mediterráneo. Sci. Mar. 55(Suppl 1): 1-133.

Delgado, M., M. Latasa and M. Estrada. 1992. Variability in the size-fractionated distribution of the phytoplankton across the Catalan front of the north-west Mediterranean. J. Plankton Res. 14: 753-771.

Descy, J.-P. and C. Willems. 1991. Contribution to the knowledge of the River Moselle phytoplankton. Cryptogam. Algol. 12: $87-100$.

Dìez, B., C. Pedròs-Aliò, T.L. Marsh and R. Massana. 2001. Application of denaturing gradient gel electrophoresis (DGGE) to study the diversity of marine picoeukaryotic assemblages and comparison of DGGE with other molecular techniques. Appl. Environ. Microbiol. 67: 2942-2951.

Dodge, J.D. 1975. The Prorocentrales (Dinophyceae). II. Revision of the taxonomy within the genus Prorocentrum. Bot. J. Linn. Soc. 71: 103-125.

D'Ortenzio F. and M. Ribera d'Alcalà. 2009. On the trophic regimes of the Mediterranean Sea: a satellite analysis. Biogeosciences 6 : $139-148$.

Duarte, C.M., S. Agustí, H. Kennedy and D. Vaqué. 1999. The Mediterranean climate as a template for Mediterranean marine ecosystems: the example of the northeast Spanish littoral. Prog. Oceanogr. 44: 245-270.

Estrada, M. 1979. Observaciones sobre la heterogeneidad del fitoplancton en una zona costera del mar Catalan. Inv. Pesq. 43: 637-666.

Estrada, M. 1982. Phytoplankton of the western Mediterranean at the beginning of autumn. Int. Rev. Gesamten Hydrobiol. Hydrogr. 67: 517-532.

Estrada, M. 1991. Phytoplankton assemblages across a NW Mediterranean front: changes from winter mixing to spring stratification. Oecol. Aquat. 10: 157-185.

Estrada, M., R.A. Varela, J. Salat, A. Cruzado and E. Arias. 1999. Spatio-temporal variability of the winter phytoplankton distribution across the Catalan and North Balearic fronts (NW Mediterranean). J. Plankton Res. 21: 1-20.

Faust, M.A., J. Larsen and Ø. Moestrup. 1999. Potentially toxic phytoplankton. 3. Genus Prorocentrum (Dinophyceae). In: (J.A. Lindley, ed) ICES identification leaflets for plankton. ICES, Leaflet no. 184, Copenhagen. pp. 1-24.
Fensome, R.A., F.J.R. Taylor, G. Norris, W.A.S. Sarjeant, D.J. Wharton and G.L. Williams. 1993. A classification of living and fossil dinoflagellates. Micropaleontology, Special Publication Number 7. Sheridan Press, Hanover. pp. 351.

Gaarder, K.R. 1954. Dinoflagellatae from the Michael Sars North Atlantic deep sea expedition 1910. Rep. Scient. Results Michael Sars N. Atlant. Deep Sea Exped. 1910, University of Bergen, John Grieg, Bergen 2: 1-62.

Gaarder, K.R. and B.R. Heimdal. 1977. A revision of the genus Syracosphaera Lohmann (Coccolithineae). Meteor. Forsch. Ergebn. D. 24: 54-71.

Gao, Y.-H., Z.-D. Cheng and D.-X. Jin. 1992. Minidiscus a new recorded nanodiatom genus from China. Acta Phytotaxon. Sin. 30: 273-296.

Gardner, C. and R.M. Crawford. 1992. A description of the diatom Papiliocellulus simplex sp. nov. (Cymatosiraceae, Bacillariophyta) using light and electron microscopy. Phycologia 31: 246-252.

Gascard, J.-C. 1978. Mediterranean deep water formation, baroclinic instability and oceanic eddies. Oceanol. Acta 1: 315-330.

Genkal, S.I. and V.I. Makarova. 1985. Diatomvye vodorosli, novye dlya planktona Kapiiiskogo i Azoskogo morei (Bacillariophyta planctonica nova e maribus Caspio et Maeotico). Nov. Sist. Nizhi. Rastenii 22: 35-37.

Giuffré, G., R.M. Palmieri and D. Tomasello. 1991. Seasonal sequences of diatom colonization in a vertical profile in a Mediterranean meromictic brackish lake. G. Bot. Ital. 125: 817-830.

Gómez, F. 2003. Checklist of Mediterranean free-living dinoflagellates. Bot. Mar. 46: 215-242.

Gómez, F. 2005. A list of free-living dinoflagellate species in the world's oceans. Acta Bot. Croat. 64: 129-212.

Gourret, P.A.M. 1883. Sur les Péridiniens du golfe de Marseille. Ann. Mus. Hist. Nat. Marseille 8: 1-37.

Gran, H.H. and T. Braarud. 1935. A quantitative study of the phytoplankton in the Bay of Fundy and the Gulf of Maine (including observations on hydrography, chemistry and turbidity). J. Biol. Board Can. 1: 279-467.

Hallegraeff, G.M. 1984. Species of the diatom genus Thalassiosira in Australian waters. Bot. Mar. 27: 495-513.

Hansen, G. 1995. Analysis of the thecal plate pattern in the dinoflagellate Heterocapsa rotundata (Lohmann) comb. nov. (=Katodinium rotundatum (Lohmann) Loeblich). Phvcologia 34: 166-170.

Hansen, G. and J. Larsen. 1992. Dinoflagellater i danske farvande. In: (H.A. Thomsen, ed) Plankton $i$ de indre danske farvande. Havforskning fra Miljøstyrelsen 11. Scantryk, Copenhagen. pp. 45-155.

Harris, A.S.D., L.K. Medlin, J. Lewis and K.J. Jones. 1995. Thalassiosira species (Bacillariophyceae) from a Scottish sea-loch. Eur. J. Phycol. 30: 117-131.

Hasle, G.R. 1972. Thalassiosira subtilis (Bacillariophyceae) and two allied species. Norw. J. Bot. 19: 111-137.

Hasle, G.R. 1973. Thalassiosiraceae, a new diatom family. Norw. J. Bot. 20: 67-69.

Hasle, G.R. 1978. Some Thalassiosira species with one central process (Bacillariophyceae). Norw. J. Bot. 25: 77-110.

Hasle, G.R. and G.A. Fryxell. 1977. The genus Thalassiosira, some species with a linear areola array. Nova Hedwigia, Beih. 54: $15-66$.

Hasle, G.R. and E.E. Syvertsen. 1997. Marine diatoms. In: (C.R. Tomas, ed) Identifying marine phytoplankton. Academic Press, San Diego. pp. 5-385.

Hasle, G.R., H.A. von Stosch and E.E. Syvertsen. 1983. Cymatosiraceae, a new diatom family. Bacillaria 6: 9-156. 
Heimdal, B.R. 1993. Modern coccolithophorids. In: (C.R. Tomas, ed) Identifying marine phytoplankton. Academic Press, San Diego. pp. $731-858$.

Heimdal, B.R. and K.R. Gaarder. 1980. Coccolithophorids from the northern part of the eastern central Atlantic. I. Holococcolithophorids. Meteor Forsch. Ergebn. 32: 1-14.

Heimdal, B.R. and K.R. Gaarder. 1981. Coccolithophorids from the northern part of the eastern central Atlantic. II. Heterococcolithophorids. Meteor Forsch. Ergebn. 33: 37-69.

Hendey, N.I. 1964. An introductory account of the smaller algae of British coastal waters. V. Bacillariophyceae (Diatoms). Her Majesty's Stationery Office, London. pp. 317.

Hill, D.R.A. 1991. A revised circumscription of Cryptomonas (Cryptophyceae) based on examination of Australian strains. Phycologia 30: 170-188.

Hill, D.R.A. 1992a. Plagioselmis prolonga Butcher (Cryptophyceae). Ann. Bot. Fenn. 29: 165-166.

Hill, D.R.A. 1992b. Teleaulax acuta (Butcher) Hill (Cryptophyceae). Baltic Sea Phytoplankton identification Sheet No. 12. Ann. Bot. Fenn. 29: 173-174.

Hodgkiss, I.J. and Z.B. Yang. 2001. New and dominant species from Sam Xing Wan, Sai Kung during the 1998 massive fish killing red tide in Hong Kong. In: (G.M. Hallegraeff, S.I. Blackburn, C.J. Bolch and R.J. Lewis, eds) Harmful algal blooms. Intergovermental Oceanographic Commission of UNESCO, Paris. pp. 62-65.

Hoppenrath, M. 2004. A revised checklist of planktonic diatoms and dinoflagellates from Helgoland (North Sea, German Bight). Helgol. Mar. Res. 58: 243-251.

Hoppenrath, M., M. Elbrächter and G. Drebes. 2009. Marine phytoplankton: selected microphytoplankton species from the North Sea around Helgoland and Sylt. E. Schweizerbart'sche Verlagsbuchhandlung, Stuttgart. pp. 264.

Horiguchi, T. 1990. Prorocentrum dentatum. In: (Y. Fukuyo, ed) Red tide organisms in Japan. Japan Fisheries Resource Conservation Association, Tokyo. pp. 26-27.

Iennaco, I. 2004. Evoluzione spaziale del fitoplancton in un esperimento lagrangiano nel Mediterraneo Nord-Occidentale. Tesi di Laurea. Università degli Studi di Napoli Parthenope. pp. 175.

Jacques, G., H.J. Minas, M. Minas and P. Nival. 1973. Influence des conditions hivernales sur les productions phyto et zooplanctoniques en Méditerranée Nord-Occidentale. II: Biomasse et production phytoplanctonique. Mar. Biol. 23: 251-265.

Kamptner, E. 1954. Untersuchungen über den Feinbau der Coccolithen. Arch. Protistenkd. 100: 1-90.

Kamptner, E. 1963. Coccolithinen-skelettreste aus Tiefseeablagerungen des Pazifischen Ozeans. Ann. Nathist. Mus. Wien 66: 139-204.

Keller, M.D., R.C. Selvin, W. Claus and R.R.L. Guillard. 1987. Media for the culture of oceanic ultraphytoplankton. J. Phycol. 23: 633-638.

Kimor, B. and E.J.F. Wood. 1975. A plankton study in the eastern Mediterranean Sea. Mar. Biol. 29: 321-333.

Kleijne, A. 1993. Morphology, taxonomy and distribution of extant coccolithophorids (Calcareous nannoplankton). Ph.D. Thesis. University of Amsterdam, Amsterdam. pp. 321.

Kleijne, A. and L. Cros. 2009. Ten new extant species of the coccolithophore Syracosphaera and a revised classification scheme for the genus. Micropaleontology 55: 425-462.

Knappertsbusch, M. 1993. Geographic-distribution of living and Holocene coccolithophores in the Mediterranean Sea. Mar. Micropaleontol. 21: 219-247.

Koray, T. 2001. Türkiye Denizleri Fitoplankton Türleri Kontrol Listesi (A check-list for phytoplankton of Turkish seas). J. Fish. Aquat. Sc. 18: 1-23.
Kuylenstierna, M. and B. Karlson. 1994. Seasonality and composition of pico- and nanoplanktonic cyanobacteria and protists in the Skagerrak. Bot. Mar. 37: 17-33.

Kuylenstierna, M. and B. Karlson. 2000. Checklist of phytoplankton in Skagerrak-Kattegat. http://www.marbot.gu.se/SSS/SSShome. (last access 03/05/2010).

Lacombe, H., J.-C. Gascard, J. Gonella and J.P. Bethoux. 1981. Response of the Mediterranean to the water and energy fluxes across its surface, on seasonal and interannual scales. Oceanol. Acta 4: 247-255.

Lange, C. 1985. Spatial and seasonal variations of diatom assemblages off the Argentinian coast (Southwestern Atlantic). Oceanol. Acta 8: 361-369.

Lecal, J. 1965. Coccolithophorides littoraux de Banyuls. Vie Milieu 16: 251-270.

Levy, M., L. Memery and G. Madec. 1999. The onset of the spring bloom in the MEDOC area: mesoscale spatial variability. DeepSea Res. I 46: 1137-1160.

Lewis, J. and J.D. Dodge. 1987. The cyst-theca relationship of Protoperidinium americanum (Gran and Braarud) Balech. J. Micropaleontol. 6: 113-121.

Li, W.K.W. 1994. Primary productivity of prochlorophytes, cyanobacteria, and eucaryotic ultraphytoplankton measurements from flow cytometric sorting. Limnol. Oceanogr. 39: 169-175.

Lohmann, H. 1902. Die Coccolithophoridae, eine Monographie der Coccolithen bildenden Flagellaten, zugleich ein Beitrag zur Kenntnis des Mittelmeerauftriebs. Arch. Protistenkd. 1: 89-165.

Lu, D. and J. Goebel. 2001. Five red tide species in genus Prorocentrum including the description of Prorocentrum donghaiense Lu sp. nov. from the East China Sea. Chin. J. Oceanol. Limnol. 19: 337-344.

Lu, D., J. Goebel, Y. Qi, J. Zou, X. Han, Y. Gao and Y. Li. 2005. Morphological and genetic study of Prorocentrum donghaiense $\mathrm{Lu}$ from the East China Sea, and comparison with some related Prorocentrum species. Harmful Algae 4: 493-505.

Malinverno, E., M.D. Dimiza, M.V. Triantaphyllou, M.D. Dermitzakis and C. Corselli. 2008. Coccolithophores of the Eastern Mediterranean Sea: a look into the marine microworld. ION Publications, Peristeri. pp. 183.

Marañón, E., P.M. Holligon, R. Barciela, N. Gonzàlez, B. Mourino, M.J. Pazò and M. Varela. 2001. Patterns of phytoplankton size structure and productivity in contrasting open-ocean environments. Mar. Ecol. Prog. Ser. 216: 43-56.

Margalef, R. 1969. Composición específica del fitoplancton de la costa catalano-levantina (Mediterráneo occidental) en 19621967. Invest. Pesq. 33: 345-380.

Margalef, R. 1974. Ecologia. Omega, Barcelona. pp. 951.

Margalef, R. 1995. Fitoplancton del NW del Mediteraneo (Mar Catalan) en junio del 1993, y factores que condicionan su producción y distribucción. Mem. R. Acad. Ciencias Artes Barcelona 60: $3-56$.

Marino, D. and M. Modigh. 1981. An annotated check-list of planktonic diatoms from the Gulf of Naples. Mar. Ecol. 2: 317-333.

Marshall, J. and F. Schott. 1979. Open ocean convection: observations, theory, and models. Rev. Geophvs. 37: 1-64.

Massana, R., J. Castresana, V. Balagué, L. Guillou, K. Romari, A. Groisillier, K. Valentin and C. Pedròs-Aliò. 2004. Phylogenetic and ecological analysis of novel marine stramenopiles. Appl. Environ. Microbiol. 70: 3528-3534.

McDonald, S.M., D. Sarno, D.J. Scanlan and A. Zingone. 2007. Genetic diversity of eukaryotic ultraphytoplankton in the Gulf of Naples during an annual cycle. Aquat. Microb. Ecol. 50: $75-89$. 
Medlin, L. and A. Zingone. 2007. A taxonomic review of the genus Phaeocystis. Biogeochemistry 83: 3-18.

MEDOC. 1970. Observation of formation of deep water in the Mediterranean Sea. Nature 227: 1037-1040.

Millot, C. 1987. Circulation in the Western Mediterranean Sea. Oceanol. Acta 10: 143-149.

Millot, C. 1999. Circulation in the Western Mediterranean Sea. $J$. Mar. Svst. 20: 423-442.

Montresor, M., A. Zingone and D. Sarno. 1998. Dinoflagellate cyst production at a coastal Mediterranean site. J. Plankton Res. 20: 2291-2312.

Nikolaidis, G. and M. Moustaka-Gouni. 1990. The structure and dynamics of phytoplankton assemblages from the inner part of the Thermaikos Gulf, Greece. I. Phytoplankton composition and biomass from May 1988 to April 1989. Helgol. Meeresunters 44: 487-501.

Novarino, G. 2005. Nanoplankton protists from the western Mediterranean Sea. II. Cryptomonads (Cryptophyceae $=$ Cryptomonadea). Sci. Mar. 69: 47-74.

Novarino, G., I.A.N. Lucas and S. Morrall. 1994. Observations on the genus Plagioselmis (Cryptophyceae). Cryptogam. Algol. 15: 87-107.

Novarino, G., D.K. Millis and F. Hannah. 1997. Pelagic flagellate populations in the southern North Sea, 1988-89. I. Qualitative observations. J. Plankton Res. 19: 1081-1109.

Okada, H. and A. McIntyre. 1977. Modern coccolithophores of the Pacific and North Atlantic Oceans. Micropaleontology 23: 1-55.

Parke, M. and P.S. Dixon. 1976. Checklist of British marine algae - 3rd revision. J. Mar. Biol. Ass. UK 56: 527-594.

Parke, M., I. Manton and B. Clarke. 1955. Studies on marine flagellates. II. Three new species of Chrysochromulina. J. Mar. Biol. Ass. UK 34: 579-609.

Pastoureaud A., C. Dupuy, M.-J. Chrétiennot-Dinet, F. Lantoine and P. Lioret. 2003. Red coloration of oysters along the French Altantic coast during the 1998 winter season: implication of nanoplanktonic cryptophytes. Aquaculture 228: 225-235.

Pavillard, J. 1905. Recherches sur la flore pélagique (phytoplancton) de l'Étang de Thau. Mém. Univ. Montpellier 2: 1-116.

Pavillard, J. 1916a. Recherches sur les Péridiniens du Golfe du Lion. Trav. Inst. Bot. Univ. Montpellier 4: 9-70.

Pavillard, J. 1916b. Recherches sur les diatomées pélagiques du Golfe du Lion. Trav. Inst. Bot. Univ. Montpellier et St. Zool. Sète 5: 7-62.

Peragallo, H. and M. Peragallo. 1897-1908. Diatomées marines de France et des districts maritimes voisins. M.J. Tempère, Grezsur-Loing. pp. 492.

Pomroy, A.J. 1989. Scanning electron microscopy of Heterocapsa minima sp. nov. (Dinophyceae) and its seasonal distribution in the Celtic Sea. Br. Phycol. J. 24: 131-135.

Proschkina-Lavrenko, A.I. 1961. Diatomeae novae e Mari Nigro (Ponto Euxino) et Azoviano (Maeotico). Notul. Syst. Inst. Cryptog. 14: 33-39.

Qi, Y. and Y. Yang. 2003. What the Prorocentrum species could be? A review in a Prorocentrum bloom species classification where it initiated in ECS. Chin. J. Appl. Ecol. 14: 1188-1190.

Ribera d'Alcalà, M., F. Conversano, F. Corato, P. Licandro, O. Mangoni, D. Marino, M.G. Mazzocchi, M. Modigh, M. Montresor, M. Nardella, V. Saggiomo, D. Sarno and A. Zingone. 2004. Seasonal patterns in plankton communities in a pluriannual time series at a coastal Mediterranean site (Gulf of Naples): an attempt to discern recurrences and trends. Sci. Mar. 68 (Suppl. 1): $65-83$.

Robinson, A.R. and M. Golnaraghi. 1995. The physical and dynamical oceanography of the Mediterranean sea. In: (P. Malanotte-
Rizzoli and A.R. Robinson, eds) Ocean processes in climate dynamics: global and Mediterranean examples. Proceedings of NATO-ASI. Kluwer Academic Publishers, Dordrecht. pp. 255-306.

Round, F.E., R.M. Crawford and D.G. Mann. 1990. The diatoms. Biology and morphology of the genera. Cambridge University Press, Cambridge. pp. 743.

Samtleben, C. 1980. Die Evolution der Coccolithophoriden-Gattung Gephyrocapsa nach Befunden im Atlantik. Paleontol. Z. 54: 91-127.

Samtleben, C. and A. Schröder. 1990. Coccolithophoriden Gemeinschaften und Coccolithen-Sedimentation im Europäischen Nordmeer. Zur Abbildung von Planktonzönosen im Sediment. Ber. Sonderforschungsbereich, 313 Kiel 25: 1-52.

Samtleben, C., P. Schafer, H. Andruleit, A. Baumann, K.H. Baumann, A. Kohly, J. Matthiessen and A. Schroderritzrau. 1995. Plankton in the Norwegian Greenland Sea - from living communities to sediment assemblages - an actualistic approach. Geol. Rundsch. 84: 108-136.

Saugestad, A.H. and B.R. Heimdal. 2002. Light microscope studies on coccolithophorids from the western Mediterranean Sea, with notes on combination cells of Daktylethra pirus and Syracosphaera pulchra. Plant Biosvst. 136: 3-28.

Schiller, J. 1925. Die plantonischen Vegetationen des adriatischen Meeres. A. Die Coccolithophoriden-Vegetation in den Jahren 1911-14. Arch. Protistenkd. 53: 59-123.

Schiller, J. 1933. Dinoflagellatae (Peridineae) in monographischer Behandlung 1. Teil. Akademische Verlagsgesellschaft, Leipzig, pp. 617.

Siano, R., W.H.C.F. Kooistra, M. Montresor and A. Zingone. 2009. Unarmoured and thin-walled dinoflagellates from the Gulf of Naples, with the description of Woloszynskia cincta sp. nov. (Dinophyceae, Suessiales). Phvcologia 48: 44-65.

Silva, P., J. Throndsen and W. Eikrem. 2007. Revisiting the nomenclature of haptophytes. Phvcologia 46: 471-475.

Siokou-Frangou, I., U. Christaki, M.G. Mazzocchi, M. Montresor, M. Ribera d'Alcalà, D. Vaqué and A. Zingone. 2010. Plankton in the open Mediterranean Sea: a review. Biogeosciences 7: 1543-1586.

Sur, H.I., E. Ozsoy and U. Unluata. 1993. Simultaneous deep and intermediate depth convection in the Northern Levantine Sea, winter 1992. Oceanol. Acta 16: 33-43.

Takahashi, K. 1981. Vertical flux, ecology and dissolution of Radiolaria in tropical oceans: implications from the silica cycle. $\mathrm{PhD}$ Thesis, Massachusetts Institute of Technology/Woods Hole Oceanographic Institution. pp. 461.

Takano, H. 1981. New and rare diatoms from Japanese marine waters. VI. Three new species in Thalassiosiraceae. Bull. Tokai Reg. Fish. Res. Lab. 105: 31-43.

Taylor, F.J.R. 1967. Phytoplankton of the south western Indian ocean. Nova Hedwigia 12: 433-476.

Taylor, F.J.R. and R.E. Waters. 1982. Spring phytoplankton in the subarctic North Pacific Ocean. Mar. Biol. 67: 323-335.

Thomsen, H.A. 1986. A survey of the smallest eukaryotic organisms of the marine phytoplankton. Can. Bull. Fish. Aquat. Sci. 214: 121-158.

Throndsen, J. 1969. Flagellates of Norwegian coastal waters. Nytt. Mag. Bot. 16: 161-216.

Throndsen, J. 1997. The planktonic marine flagellates. In: (C.R. Tomas, ed) Identifying marine phytoplankton. Academic Press, San Diego. pp. 591-729.

Travers, M. 1971. Diversité du microplancton du Golfe de Marseille en 1964. Mar. Biol. 8: 308-343. 
Travers, M. 1975. Inventaire des protistes du Golfe de Marseille et de ses parages. Ann. Bot. Fenn. 51: 51-75.

Vaulot, D., W. Eikrem, M. Viprey and H. Moreau. 2008. The diversity of small eucaryotic phytoplankton $(\leq 3 \mu \mathrm{m})$ in marine ecosystems. FEMS Microbiol. Rev. 32: 765-820.

Velasquez, Z.R. and A. Cruzado. 1995. Inventory of the diatom flora of the NW Mediterranean Sea. Vie Milieu 45: 249-263.

Williams, P.J.I.B. 1998. The balance of plankton respiration and photosynthesis in the open ocean. Nature 394: 55-57.

Winter, A., Z. Reiss and B. Luz. 1979. Distribution of living coccolithophore assemblages in the Gulf of Elat (Aqaba). Mar. Micropaleontol. 4: 197-223.

Winter, A., B. Rost, H. Hilbrecht and M. Elbrächter. 2002. Vertical and horizontal distribution of coccolithophores in the Caribbean Sea. Geo-Mar. Lett. 22: 150-161.

Worden, A.Z., J.K. Nolan and B. Palenick. 2004. Assessing the dynamics and ecology of marine picophytoplankton: the impor- tance of the eucaryotic component. Limnol. Oceanogr. 49: $168-179$.

Yoshida, M., M.-H. Noël, T. Nakayama, T. Naganuma and I. Inouye. 2006. A haptophyte bearing siliceous scales: ultrastructure and phylogenetic position of Hyalolithus neolepis gen. et sp. nov. (Prymnesiophyceae, Haptophyta). Protist 157: 213-234.

Young, J.R., M. Geisen, L. Cros, A. Kleijne, C. Sprengel, I. Probert and J.B. Østergaard. 2003. A guide to extant coccolithophore taxonomy. J. Nannoplankton Res. Spec. Issue 1: 1-132.

Zingone, A., M.-J. Chrétiennot-Dinet, M. Lange and L. Medlin. 1999. Morphological and genetic characterization of Phaeocystis cordata and Phaeocystis jahnii (Prymnesiophyceae), two new species from the Mediterranean Sea. J. Phycol. 35: 1322-1337.

Received 31 May, 2010; accepted 3 February, 2011 